Provided for non-commercial research and education use. Not for reproduction, distribution or commercial use.

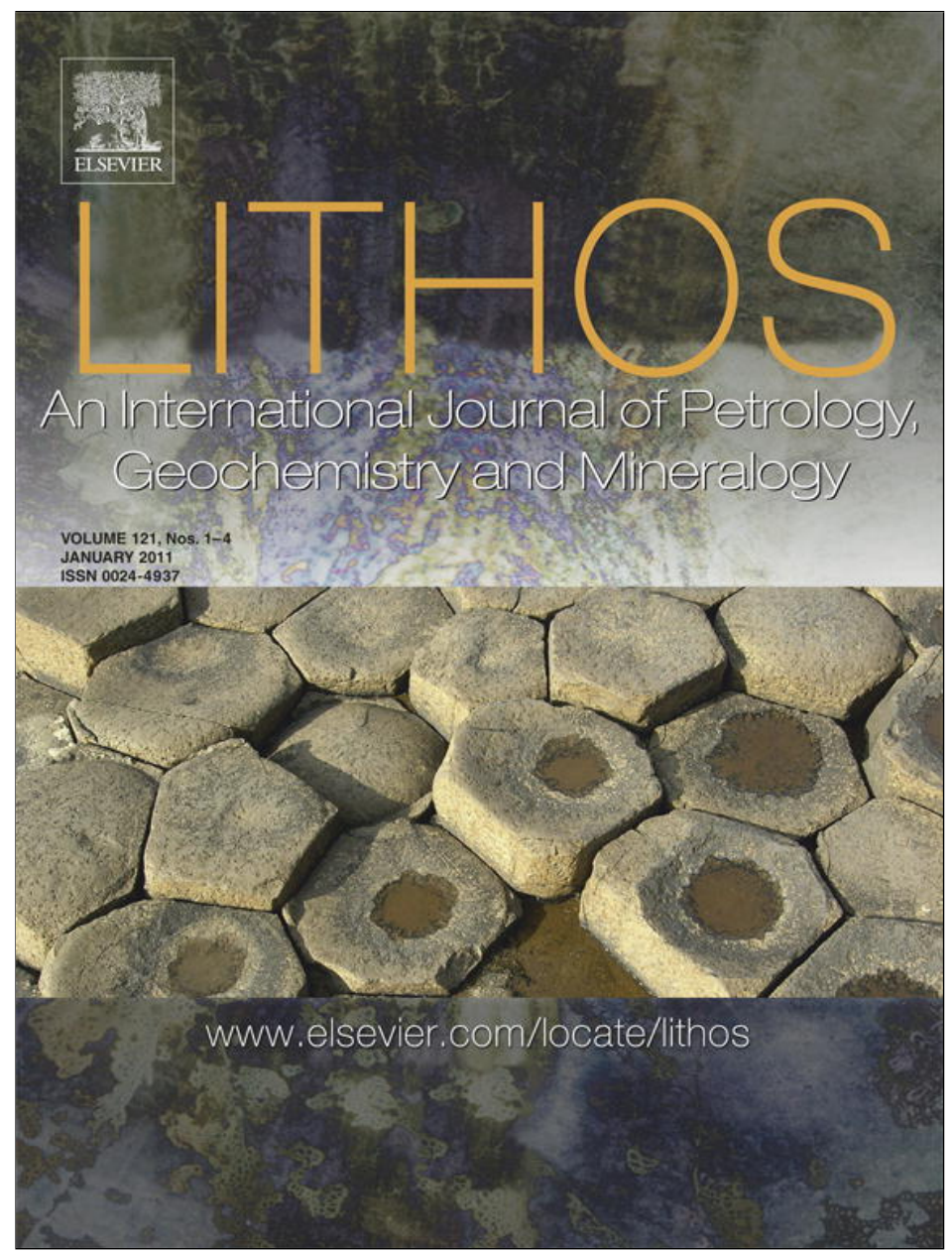

This article appeared in a journal published by Elsevier. The attached copy is furnished to the author for internal non-commercial research and education use, including for instruction at the authors institution and sharing with colleagues.

Other uses, including reproduction and distribution, or selling or licensing copies, or posting to personal, institutional or third party websites are prohibited.

In most cases authors are permitted to post their version of the article (e.g. in Word or Tex form) to their personal website or institutional repository. Authors requiring further information regarding Elsevier's archiving and manuscript policies are encouraged to visit:

http://www.elsevier.com/copyright 


\title{
Plume-subduction interaction in southern Central America: Mantle upwelling and slab melting
}

\author{
Esteban Gazel ${ }^{\mathrm{a}, *}$, Kaj Hoernle ${ }^{\mathrm{b}}$, Michael J. Carr ${ }^{\mathrm{c}}$, Claude Herzberg ${ }^{\mathrm{c}}$, Ian Saginor ${ }^{\mathrm{d}}$, Paul van den Bogaard ${ }^{\mathrm{b}}$, \\ Folkmar Hauff $^{\text {b }}$, Mark Feigenson ${ }^{\mathrm{c}}$, Carl Swisher III ${ }^{\mathrm{c}}$ \\ ${ }^{a}$ Lamont-Doherty Earth Observatory of Columbia University, PO Box 1000, 61 Rt. 9 W Palisades, NY 10964, USA \\ b IFM-GEOMAR, Wischhofstrasse 1-3, 24148 Kiel, Germany \\ c Department of Earth and Planetary Sciences, Rutgers University, 610 Taylor Road, Piscataway, NJ 08854, USA \\ ${ }^{\mathrm{d}}$ Keystone College, La Plume, PA, 18440, USA
}

\section{A R T I C L E I N F O}

\section{Article history:}

Received 19 July 2010

Accepted 15 October 2010

Available online 30 October 2010

\section{Keywords:}

Central America

Galapagos Plume

Alkaline basalt

Adakite

Mantle potential temperatures

Lithosphere-asthenosphere

\begin{abstract}
A B S T R A C T
The volcanic front in southern Central America is well known for its Galapagos OIB-like geochemical signature. A comprehensive set of geochemical, isotopic and geochronological data collected on volumetrically minor alkaline basalts and adakites were used to better constrain the mantle and subduction magma components and to test the different models that explain this OIB signature in an arc setting. We report a migration of back-arc alkaline volcanism towards the northwest, consistent with arc-parallel mantle flow models, and a migration towards the southeast in the adakites possibly tracking the eastward movement of the triple junction where the Panama Fracture Zone intersects the Middle America Trench. The adakites major and trace element compositions are consistent with magmas produced by melting a mantle-wedge source metasomatized by slab derived melts. The alkaline magmas are restricted to areas that have no seismic evidence of a subducting slab. The geochemical signature of the alkaline magmas is mostly controlled by upwelling asthenosphere with minor contributions from subduction components. Mantle potential temperatures calculated from the alkaline basalt primary magmas increased from close to ambient mantle $\left(\sim 1380-1410{ }^{\circ} \mathrm{C}\right)$ in the Pliocene to $\sim 1450{ }^{\circ} \mathrm{C}$ in the younger units. The calculated initial melting pressures for these primary magmas are in the garnet stability field (3.0-2.7 GPa). The average final melting pressures range between 2.7 and $2.5 \mathrm{GPa}$, which is interpreted as the lithosphere-asthenosphere boundary at $\sim 85-$ $90 \mathrm{~km}$. We provide a geotectonic model that integrates the diverse observations presented here. The slab detached after the collision of the Galapagos tracks with the arc ( 10-8 Ma). The detachment allowed hotter asthenosphere to flow into the mantle wedge. This influx of hotter asthenosphere explains the increase in mantle potential temperatures, the northwest migration in the back-arc alkaline lavas that tracks the passage of the hotter asthenosphere, and the presence of a slab melting signature in the volcanic front caused by recycling of Galapagos Hotspot tracks.
\end{abstract}

(C) 2010 Elsevier B.V. All rights reserved.

\section{Introduction}

The interaction between a mantle plume and a subduction system can cause geochemical and geodynamic deviations from "normal" arc magmatism. Direct arc-plume interaction can occur if an arc passes over a mantle plume or if an arc is close enough to the influence of a mantle plume. For example, geophysical and geochemical evidence suggest that asthenosphere from the Samoa Plume flows beneath the Lau Basin into the northern segment of the Tonga-Kermadec arc (Wendt et al., 1997; Turner and Hawkesworth, 1998; Smith et al., 2001). An indirect interaction can cause similar geochemical results when the eruptive products of a plume (e.g. seamount tracks) subduct

\footnotetext{
* Corresponding author. Tel.: +1 845365 8507; fax: +1 8453658155 E-mail address: egazel@ldeo.columbia.edu (E. Gazel).
}

beneath an arc. Subduction of hotspot tracks can "re-fertilize" the arc mantle wedge by metasomatic processes related to oceanic crust recycling. Subsequent melting of this metasomatized mantle can produce lavas with an ocean island basalt (OIB) signature in an arc setting (Gazel et al., 2009). Wendt et al. (1997) reported $\mathrm{Pb}$ radiogenic isotope and trace element evidence for this type of interaction where the Louisville seamount track is subducting beneath the central portion of the Tonga-Kermadec Arc.

The OIB signature in alkaline lavas from the Mexican volcanic belt has been attributed to mantle plume activity below the arc (Márquez et al., 1999). Recent evidence, however, suggests that this signature in Mexico is caused by mantle re-fertilization by recycling of oceanic crust (Straub et al., 2008) rather than a mantle plume. Bryant et al. (2006) reported $\mathrm{Pb}, \mathrm{Sr}$, and $\mathrm{Nd}$ isotopes and trace element evidence for the interaction between melts from the subducting Carnegie Ridge (Galapagos Plume track) and the mantle wedge in the northern 
Andean volcanic zone in Ecuador. In the northern Marianas the subduction of the Wake and Magellan seamounts (Koppers et al., 1998) also correlates with an enriched geochemical and $\mathrm{Pb}$-isotopic signature of the eruptive lavas (Peate and Pearce, 1998; Ishizuka et al., 2007; Benjamin et al., 2007). In summary, independent of the nature of the interaction between a mantle plume (or the eruptive products of a plume) and an arc system, the result could be arc lavas with OIBlike geochemical signature in a subduction setting.

The volcanic front lavas in central Costa Rica are well known for their enriched OIB-like signature (e.g., Reagan and Gill, 1989; Herrstrom et al., 1995; Gazel, 2003; Feigenson et al., 2004; Hoernle et al., 2008; Gazel et al., 2009). Herrstrom et al. (1995) suggested that trench-parallel mantle flow above the subducting Nazca Plate brings this enriched component from the South American mantle wedge. Abratis and Wörner (2001) suggested that a "slab window" in the subducting Cocos Plate, proposed by Johnston and Thorkelson (1997) allows Galapagos-modified asthenosphere to flow into the Central American subduction system. Feigenson et al. (2004) explained the OIB signature by re-melting of mantle modified by the Galapagos Plume beneath central Costa Rica and Panama. Conversely, Goss and Kay (2006) proposed generating the OIB-like signature of the central Costa Rican volcanic front by incorporating fore-arc oceanic complexes into the mantle wedge by tectonic erosion.

Recent studies have provided convincing evidence that this anomalous OIB-like signature in the volcanic front is derived from the interaction of the mantle wedge with the Galapagos Hostpot tracks subducting beneath Costa Rica and Panama (Benjamin et al., 2007; Hoernle et al., 2008; Gazel et al., 2009). The most recent study about the evolution of the volcanic front in Panama reported by Wegner et al. (2010) proposed a long-term interaction of the arc with the Galapagos Plume, analogous to the one reported in Costa Rica by Gazel et al. (2009).

The previous mentioned studies focused on the active Central American volcanic front. This study focuses on volumetrically minor alkaline basalts and adakites that are geographically near or behind the active volcanic front (Fig. 1) that appeared for the first time in the geologic record after 6.5 Ma (Abratis and Wörner, 2001; Gazel et al., 2009; this study). Although the term "adakite" is controversial (Kelemen et al., 2003), we use it here to refer to magmas interpreted to be derived through melting of subducting oceanic crust and the subsequent reaction of those melts with the mantle wedge (e.g. Kay, 1978; Defant et al., 1992; Martin et al., 2005). In southern Costa Rica and Panama, adakitic lavas $<5 \mathrm{Ma}$ are exposed as individual domes or small lava flows (Abratis and Wörner, 2001; Gazel et al., 2009). By performing detailed studies in the adakites we can constrain the source of the slab melts required in the volcanic front lavas described by Hoernle et al. (2008) and Gazel et al. (2009). On the other hand, the alkaline basalts provide valuable information about the magma mantle end-members, and can be used for petrological modeling that provides information about the melting conditions. Here we will also evaluate the different models that attempt to explain the occurrence of alkaline basalts and adakites in southern Central America and their relation to the Galapagos Plume.

\section{Tectonic setting}

The Central American volcanic front extends parallel to the Middle American Trench from the Mexico-Guatemalan border to central Costa Rica, followed by a gap in recent volcanic activity from central Costa Rica to Panama (Fig. 1). The northwest segment of the arc (Guatemala) is located on Paleozoic continental crust while the southeast segment (Costa Rica-Panama) develops on the westernmost edge of the Caribbean Large Igneous Province (CLIP) (Dengo, 1985; Hauff et al., 2000; Alvarado et al., 2007).

The Central American volcanic front results from the subduction of the Cocos Plate beneath the Caribbean Plate. The convergence rate between the Cocos and Caribbean plates increases toward the southeast from $\sim 60 \mathrm{~mm} / \mathrm{yr}$ off southern Guatemala to $\sim 90 \mathrm{~mm} / \mathrm{yr}$ off southern Costa Rica (DeMets, 2001). The depth and angle of the Wadati-Benoiff zone beneath the volcanic front range from $\sim 200 \mathrm{~km}$ and $80^{\circ}$ beneath Nicaragua to $\sim 125 \mathrm{~km}$ and $50^{\circ}$ beneath central Costa Rica (Protti et al., 1994; Husen et al., 2003; Syracuse and Abers, 2006;
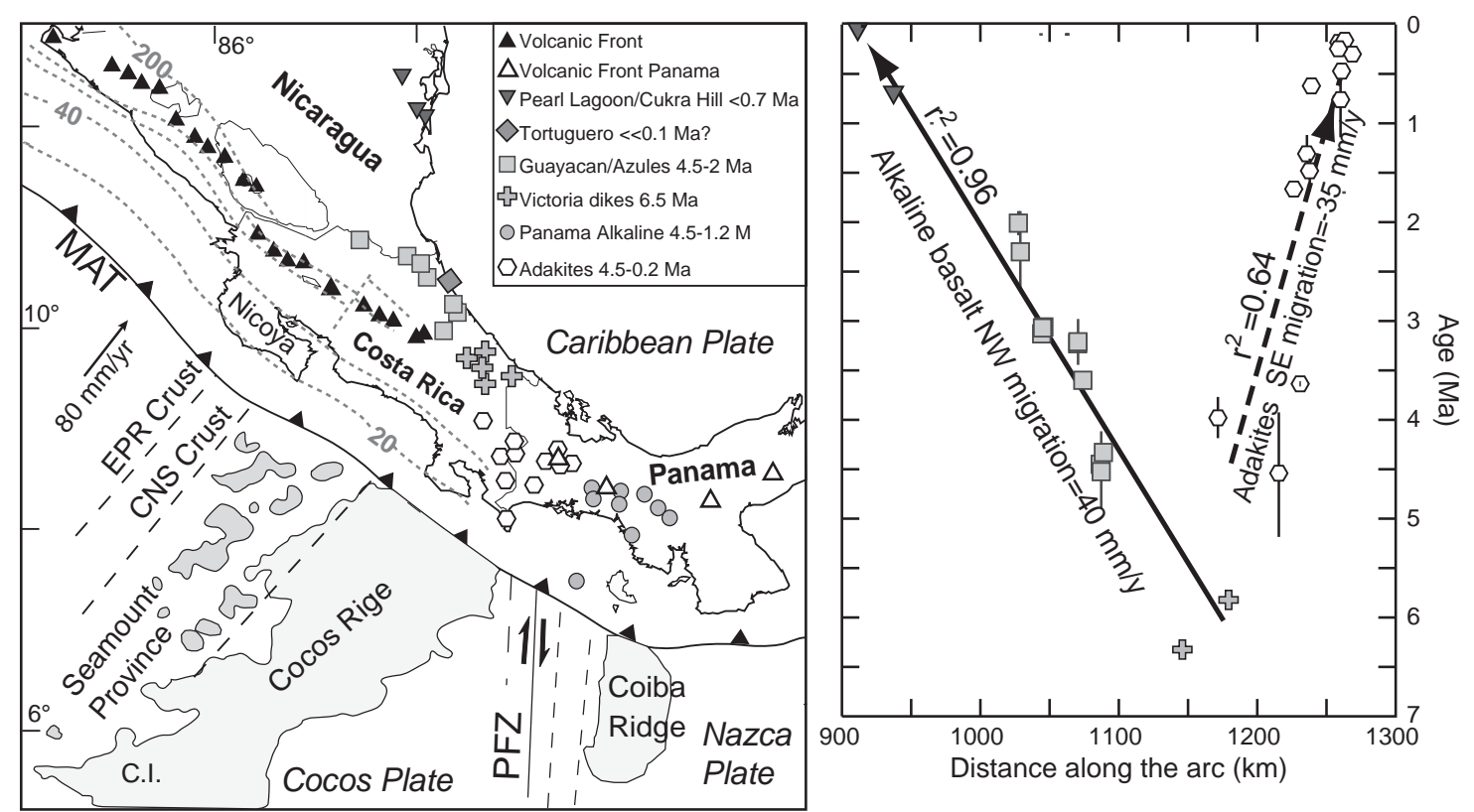

Fig. 1. Tectonic setting of southern Central America and sample locations. The Galapagos Hotspot tracks and other bathymetric features are from Werner et al. (2003). The depth contours of the subducting slab are from Protti et al. (1994). Note that the alkaline basalts in Panama and the back-arc units are restricted to areas with either no clear seismic evidence of a subducting slab (Panama) or in the back-arc (Nicaragua and Costa Rica). The adakites and alkaline basalts erupted along the volcanic front in Panama. The right panel shows the age migration of volcanism in the back-arc units from Costa Rica to Nicaragua and the units west of the Panama Fracture Zone (PFZ) from southern Costa Rica to western Panama. The rate of the northwest migration of alkaline volcanism in Costa Rica and Nicaragua is $40 \mathrm{~mm} / \mathrm{yr}$. The adakite units (west of the PFZ) have an age progression in the opposite direction of 35 mm/yr. Additional age data from Abratis and Wörner (2001) and Wegner et al. (2010). CNS: Cocos-Nazca Spreading Center, EPR: East Pacific Rise. 
Syracuse et al., 2008). Seismicity associated with the subducting Cocos Plate ends abruptly south of central Costa Rica with a maximum depth of $\sim 50 \mathrm{~km}$ (Fig. 1) (Protti et al., 1994).

Normal mid-ocean ridge basalt (N-MORB) crust produced at the East Pacific Rise subducts beneath Guatemala to northwestern Costa Rica (Fig. 1). In contrast, the oceanic crust subducting beneath central Costa Rica and Panama was formed at the Cocos-Nazca spreading center. This crust has been overprinted by Galapagos Hotspot tracks and large oceanic discontinuities caused by several fracture zones. The Middle American Trench off Costa Rica is characterized by seamount subduction and tectonic erosion (Ranero and von Huene, 2000; Vannucchi et al., 2001; Husen et al., 2002; Ranero et al., 2003; Vannucchi et al., 2006). The subducting Galapagos Hotspot tracks offshore of Costa Rica (Fig. 1) range in age between 13.0 and 14.5 Ma (Werner et al., 1999; O'Connor et al., 2007).

The subducting Galapagos Seamount Province out-board of central Costa Rica has an OIB-alkaline composition and an isotopic signature belonging to the Northern Galapagos Domain, similar to volcanic rocks from the Wolf-Darwin Lineament in the Galapagos Archipelago (Hoernle et al., 2000; Werner et al., 2003; Harpp et al., 2005). The subducting Cocos and Coiba ridges have an OIB-tholeiitic composition with a dominant isotopic composition belonging to the Central Galapagos Domain, similar to the rocks from Fernandina Island (Hoernle et al., 2000; Werner et al., 2003) (Fig. 1).

\section{Data and analytical methods}

Outcrops of olivine-bearing basaltic lavas and shallow mafic intrusions were sampled from quarries, river beds, and road cuts in the back-arc of Nicaragua and Costa Rica and along the volcanic front/ fore-arc in Panama. Adakites were sampled close to the Costa RicanPanamanian border and along the Panamanian volcanic front. Alteration-free rock chips (e.g. those free of secondary oxides, veins, and zeolites) were selected under stereoscopic microscope for geochemical studies and prepared following the methods described in Gazel et al. (2009).

Samples with minimal interstitial glass were dated by step-heating ${ }^{40} \mathrm{Ar} /{ }^{39} \mathrm{Ar}$ at Rutgers University following the methods reported in Carr et al. (2007). A subset of step-heating ${ }^{40} \mathrm{Ar} /{ }^{39} \mathrm{Ar}$ ages was collected at IFM-GEOMAR following the methods described in Hoernle et al. (2006). The plateau ages are reported in Table 1 . Examples of plateau spectra and data for each step-heating experiment are reported in the Supplementary Materials (Tables S1 and S2).

Major and selected trace element analyses (e.g. $\mathrm{Rb}, \mathrm{Sr}$, and $\mathrm{Zr}$ ) (Tables S3 and S4) were obtained at Michigan State University (MSU) from fluxed glass disks by X-ray fluorescence (XRF) in a Bruker S4 Pioneer. Additional trace elements were measured in the same glass disks using laser ablation inductively-coupled plasma mass spectrometry (LA-ICP-MS) with a Micromass Platform ICP-MS with a Cetac LSX 200+ Nd:YAG laser $(266 \mathrm{~nm})$. The methods, precision and accuracy are reported by Hannah et al. (2002). A subset of rocks (denoted with an asterisk in Tables S3 and S4, Supplementary Materials) was analyzed for major and trace elements at IFMGEOMAR. Major and selected trace elements (e.g. Rb, Sr, and $\mathrm{Zr}$ ) were collected on fused beads using a Philips X'Unique PW1480 X-ray fluorescence spectrometer (XRF) IFM-GEOMAR. Additional trace elements were determined by ICP-MS at the Institute of Geosciences (University of Kiel). The methods, precision and accuracy are described in Garbe-Schönberg (1993). A sample was split and analyzed at both MSU and IFM-GEOMAR for inter-lab analytical comparison. The analyses (sample CS-082106- 1 at MSU and TC-8 at IFM-GEOMAR) gave results in good agreement within analytical errors (Table S4).

$\mathrm{Sr}-\mathrm{Nd}-\mathrm{Pb}$ radiogenic isotopes ratios were collected on whole rock powders. Sample dissolution and element chromatography were carried out at IFM-GEOMAR following established standard proce-
Table 1

Summary of the ${ }^{40} \mathrm{Ar} /{ }^{39} \mathrm{Ar}$ step-heating plateau ages collected in this study together with GPS locations. *Ages determined at IFM-GEOMAR. Details about the step-heating experiments and examples of plateaus are in the Supplementary Materials (Tables S1 and S2). The samples with $>>0.1 \mathrm{Ma}$ age yielded a $0{ }^{40} \mathrm{Ar} /{ }^{39} \mathrm{Ar}$ ages (basically too young to be dated by this method) and were collected from cinder cones with young morphology. Geochemical data for sample GE-021306-8 in Gazel et al. (2009).

\begin{tabular}{|c|c|c|c|}
\hline Sample & Lat & Lon & Age (Ma) \\
\hline \multicolumn{4}{|c|}{ Nicaragua-Pearl Lagoon (Volcan Blue Cinder Cone) } \\
\hline AZUL-2* & 12.5500 & -83.9617 & $<<0.1$ \\
\hline \multicolumn{4}{|c|}{ Nicaragua-Cukra Hill } \\
\hline $\mathrm{CH}-011507-5$ & 12.2807 & -83.8443 & $0.74 \pm 0.03$ \\
\hline \multicolumn{4}{|c|}{ Costa Rica-Victoria Dikes } \\
\hline ES-081606-2 & 9.7114 & -83.0879 & $6.49 \pm 0.03$ \\
\hline \multicolumn{4}{|c|}{ Costa Rica-Guayacan } \\
\hline BO-062206-2 & 10.0761 & -83.5826 & $4.45 \pm 0.07$ \\
\hline BO-062306-8 & 10.0732 & -83.5597 & $4.33 \pm 0.07$ \\
\hline P-145* & 10.0723 & -83.5781 & $4.51 \pm 0.37$ \\
\hline \multicolumn{4}{|c|}{ Costa Rica-Azules (Lomas Azules) } \\
\hline AF-070306-3 & 10.3115 & -83.5734 & $3.60 \pm 0.03$ \\
\hline AF-070306-8 & 10.3614 & -83.5823 & $3.23 \pm 0.03$ \\
\hline P-163B* & 10.3559 & -83.585 & $3.25 \pm 0.21$ \\
\hline \multicolumn{4}{|c|}{ Costa Rica-Azules (Cerro Coronel) } \\
\hline CO-070206-2 & 10.6935 & -83.6441 & $3.06 \pm 0.08$ \\
\hline \multicolumn{4}{|c|}{ Costa Rica-Azules (Lomas del Colorado) } \\
\hline TO-070106-1 & 10.6465 & -83.6891 & $3.13 \pm 0.06$ \\
\hline TO-070106-3 & 10.6736 & -83.6673 & $3.07 \pm 0.06$ \\
\hline P-128* & 10.7704 & -83.7962 & $2.01 \pm 0.21$ \\
\hline \multicolumn{4}{|c|}{ Costa Rica-Tortuguero Cinder Cone } \\
\hline TO-072106-1 & 10.5866 & -83.5383 & $<<0.1$ \\
\hline \multicolumn{4}{|c|}{ Costa Rica-Aguas Zarcas Cinder Cone } \\
\hline P-152* & 10.3795 & -84.3046 & $<<0.1$ \\
\hline \multicolumn{4}{|c|}{ Costa Rica-Talamanca Adakites } \\
\hline GE-021306-8** & 9.0369 & -83.2868 & $4.23 \pm 0.02$ \\
\hline TC-3* & 9.0907 & -83.2715 & $3.98 \pm 0.20$ \\
\hline TC-5A* & 8.8498 & -82.9452 & $4.54 \pm 0.64$ \\
\hline TC-8* & 8.6248 & -82.9178 & $3.64 \pm 0.05$ \\
\hline \multicolumn{4}{|l|}{ Panama-Adakites } \\
\hline $\mathrm{M} 64 \mathrm{CKH}^{*}$ & 8.184 & -82.877 & $0.77 \pm 0.37$ \\
\hline M65aKH* & 8.470 & -82.710 & $0.23 \pm 0.08$ \\
\hline \multicolumn{4}{|l|}{ Panama-Alkaline } \\
\hline SO96-1* & 8.073 & 81.732 & $1.30 \pm 0.15$ \\
\hline CP97-1* & 8.217 & -81.587 & $1.50 \pm 0.28$ \\
\hline M105 $\mathrm{KH}^{*}$ & 8.241 & -81.791 & $1.40 \pm 0.24$ \\
\hline M118aKH* & 8.129 & -81.447 & $1.43 \pm 0.22$ \\
\hline M121aKH* & 8.188 & -81.488 & $4.45 \pm 0.35$ \\
\hline $3-12-4-03^{*}$ & 7.470 & -82.238 & $1.59 \pm 0.21$ \\
\hline
\end{tabular}

dures (e.g., Hart and Brooks, 1974). Isotopic ratios (Table 2) were determined by thermal ionization mass spectrometry (TIMS) at IFMGEOMAR on a TRITON ( $\mathrm{Sr}$ and Nd) and MAT262 $\mathrm{RPQ}^{2+}$ TIMS (Pb), operated in static multi-collection mode. $\mathrm{Sr}$ and $\mathrm{Nd}$ isotopic ratios are normalized within each run to ${ }^{86} \mathrm{Sr} /{ }^{88} \mathrm{Sr}=0.1194$ and ${ }^{146} \mathrm{Nd} /$ ${ }^{144} \mathrm{Nd}=0.7219$, respectively, and all errors are reported as 2 sigma of the mean. Reference material measured along with the samples were normalized and gave ${ }^{87} \mathrm{Sr} /{ }^{86} \mathrm{Sr}=0.710250 \pm 0.000008(\mathrm{n}=13)$ for NBS 987 and ${ }^{143} \mathrm{Nd} /{ }^{144} \mathrm{Nd}=0.511850 \pm 0.000006(\mathrm{~N}=8)$ for $\mathrm{La}$ Jolla. Sr-Nd replicate analyses of sample JK117 were within the external errors of the reference material. The long-term reproducibility of NBS $981(\mathrm{n}=197)$ is ${ }^{206} \mathrm{~Pb} /{ }^{204} \mathrm{~Pb}=16.899 \pm 0.008,{ }^{207} \mathrm{~Pb} /$ ${ }^{204} \mathrm{~Pb}=15.437 \pm 0.009,{ }^{208} \mathrm{~Pb} /{ }^{204} \mathrm{~Pb}=36.525 \pm 0.029$. Pb isotope ratios are normalized to NBS 981 values of Galer and Abouchami (1998). $\mathrm{Pb}$ replicate analyses of sample JK117 is better than $0.01 \% / \mathrm{amu}$. Total chemistry blanks are $<50 \mathrm{pg}$ for $\mathrm{Sr}-\mathrm{Nd}$ and $\mathrm{Pb}$ and thus are considered negligible.

\section{Results}

\subsection{Step-heating ${ }^{40} \mathrm{Ar} /{ }^{39} \mathrm{Ar}$ geochronology}

To study the age relations between the alkaline rocks, the adakites and the volcanic front lavas we determined 24 new ${ }^{40} \mathrm{Ar} /{ }^{39} \mathrm{Ar}$ high 
Table 2

Radiogenic isotopic ratios. Additional data for Pb and Nd isotopes from Hoernle et al. (2008). Pb isotopes from Hoernle et al. (2008) were re-normalized to NBS 981 after Galer and Abouchami (1998).

\begin{tabular}{|c|c|c|c|c|c|c|c|c|c|c|}
\hline Sample & ${ }^{87} \mathrm{Sr} /{ }^{86} \mathrm{Sr}$ & $2 \sigma$ & ${ }^{143} \mathrm{Nd} /{ }^{144} \mathrm{Nd}$ & $2 \sigma$ & ${ }^{206} \mathrm{~Pb} /{ }^{204} \mathrm{~Pb}$ & $2 \sigma$ & ${ }^{207} \mathrm{~Pb} /{ }^{204} \mathrm{~Pb}$ & $2 \sigma$ & ${ }^{208} \mathrm{~Pb} /{ }^{204} \mathrm{~Pb}$ & $2 \sigma$ \\
\hline \multicolumn{11}{|c|}{ Nicaragua-Pearl Lagoon (Volcan Blue Cinder Cone) } \\
\hline AZUL-2 & 0.703457 & 0.000005 & 0.513004 & 0.000004 & 18.948 & 0.005 & 15.560 & 0.004 & 38.601 & 0.011 \\
\hline AZUL-5 & 0.703146 & 0.000003 & 0.513024 & 0.000004 & 18.985 & 0.002 & 15.556 & 0.002 & 38.634 & 0.004 \\
\hline \multicolumn{11}{|c|}{ Nicaragua-Cukra Hill } \\
\hline $\mathrm{CH}-011507-1$ & 0.703163 & 0.000003 & 0.513018 & 0.000003 & 18.988 & 0.001 & 15.567 & 0.001 & 38.684 & 0.002 \\
\hline $\mathrm{CH}-011507-7$ & 0.703351 & 0.000003 & 0.512986 & 0.000003 & 18.948 & 0.003 & 15.569 & 0.003 & 38.599 & 0.007 \\
\hline CH-011507-9 & 0.703223 & 0.000004 & 0.513030 & 0.000003 & 18.956 & 0.002 & 15.567 & 0.001 & 38.643 & 0.003 \\
\hline \multicolumn{11}{|l|}{$\mathrm{CH}-011507-10$} \\
\hline \multicolumn{11}{|c|}{ Costa Rica-Victoria Dikes } \\
\hline D68 & 0.704119 & 0.000003 & 0.512966 & 0.000003 & 19.048 & 0.000 & 15.569 & 0.000 & 38.738 & 0.001 \\
\hline CR271 & 0.703914 & 0.000003 & 0.512975 & 0.000003 & 19.048 & 0.001 & 15.571 & 0.001 & 38.746 & 0.002 \\
\hline AM-081906-1 & 0.703744 & 0.000004 & 0.512954 & 0.000002 & 19.122 & 0.001 & 15.579 & 0.001 & 38.800 & 0.003 \\
\hline \multicolumn{11}{|c|}{ Costa Rica-Guayacan } \\
\hline P-145 & 0.703450 & 0.000002 & 0.512980 & 0.000002 & 19.051 & 0.003 & 15.562 & 0.002 & 38.684 & 0.006 \\
\hline \multicolumn{11}{|c|}{ Costa Rica-Azules (Lomas Azules) } \\
\hline P-163B & 0.703690 & 0.000002 & 0.512978 & 0.000002 & 19.061 & 0.001 & 15.559 & 0.001 & 38.704 & 0.003 \\
\hline P-164 & 0.703591 & 0.000005 & 0.512976 & 0.000004 & 19.047 & 0.003 & 15.565 & 0.002 & 38.690 & 0.006 \\
\hline \multicolumn{11}{|c|}{ Costa Rica-Azules (Lomas del Colorado) } \\
\hline P-130A & 0.703623 & 0.000006 & 0.512971 & 0.000004 & 19.171 & 0.003 & 15.587 & 0.003 & 38.857 & 0.007 \\
\hline P-138 & 0.703623 & 0.000005 & 0.512978 & 0.000003 & 19.028 & 0.002 & 15.571 & 0.002 & 38.713 & 0.005 \\
\hline CR-85 & 0.703511 & 0.000003 & 0.512918 & 0.000003 & 19.236 & 0.001 & 15.571 & 0.000 & 39.004 & 0.001 \\
\hline P-128 & 0.703807 & 0.000002 & 0.512955 & 0.000003 & 19.110 & 0.002 & 15.575 & 0.002 & 38.793 & 0.004 \\
\hline P-129 & 0.703497 & 0.000005 & 0.512961 & 0.000004 & 19.151 & 0.003 & 15.571 & 0.003 & 38.842 & 0.007 \\
\hline \multicolumn{11}{|c|}{ Costa Rica-Cerro Tortuguero Cinder Cone } \\
\hline P-132B & 0.703674 & 0.000003 & 0.512956 & 0.000004 & 19.201 & 0.001 & 15.591 & 0.001 & 38.922 & 0.003 \\
\hline P-133 & 0.703673 & 0.000006 & 0.512957 & 0.000004 & 19.188 & 0.001 & 15.573 & 0.001 & 38.880 & 0.002 \\
\hline \multicolumn{11}{|c|}{ Costa Rica-Aguas Zarcas Cinder Cones } \\
\hline P-152 & 0.703532 & 0.000005 & 0.512925 & 0.000002 & 19.288 & 0.001 & 15.576 & 0.001 & 39.107 & 0.003 \\
\hline P-153 & 0.703542 & 0.000003 & 0.512940 & 0.000002 & 19.184 & 0.003 & 15.577 & 0.002 & 38.904 & 0.005 \\
\hline P-154B & 0.703600 & 0.000002 & 0.512964 & 0.000002 & 19.093 & 0.002 & 15.564 & 0.002 & 38.758 & 0.005 \\
\hline P-155A & 0.703653 & 0.000002 & 0.512968 & 0.000002 & 19.085 & 0.002 & 15.577 & 0.002 & 38.796 & 0.005 \\
\hline \multicolumn{11}{|c|}{ Costa Rica-Talamanca Adakites } \\
\hline TC-3 & 0.703667 & 0.000003 & 0.512981 & 0.000002 & 19.017 & 0.001 & 15.551 & 0.001 & 38.674 & 0.001 \\
\hline TC-5A & 0.703509 & 0.000005 & 0.512973 & 0.000002 & 19.156 & 0.001 & 15.573 & 0.001 & 38.793 & 0.001 \\
\hline TC-6A & 0.703481 & 0.000003 & 0.512979 & 0.000002 & 19.114 & 0.001 & 15.567 & 0.000 & 38.738 & 0.001 \\
\hline TC-6b & - & - & - & - & 19.106 & 0.001 & 15.567 & 0.000 & 38.745 & 0.001 \\
\hline TC-7 & 0.703501 & 0.000004 & 0.512980 & 0.000002 & 19.106 & 0.000 & 15.567 & 0.000 & 38.745 & 0.001 \\
\hline TC- 8 & 0.703347 & 0.000003 & 0.512937 & 0.000002 & 19.333 & 0.004 & 15.578 & 0.000 & 38.969 & 0.001 \\
\hline \multicolumn{11}{|l|}{ Panama-Adakites } \\
\hline \multicolumn{11}{|l|}{ M38KH } \\
\hline M44KH & 0.703545 & 0.000005 & 0.512989 & 0.000003 & 19.213 & 0.001 & 15.581 & 0.001 & 38.886 & 0.001 \\
\hline M53KH & 0.703403 & 0.000003 & 0.512948 & 0.000003 & 19.336 & 0.001 & 15.584 & 0.001 & 39.003 & 0.002 \\
\hline M55KH & 0.703466 & 0.000005 & 0.512968 & 0.000003 & 19.202 & 0.001 & 15.583 & 0.001 & 38.880 & 0.002 \\
\hline M57aKH & 0.703568 & 0.000003 & 0.512993 & 0.000002 & 19.130 & 0.001 & 15.568 & 0.001 & 38.781 & 0.003 \\
\hline M64c KH & 0.703354 & 0.000004 & 0.512965 & 0.000002 & 19.308 & 0.001 & 15.587 & 0.001 & 38.992 & 0.002 \\
\hline M65a KH & 0.703352 & 0.000003 & 0.512970 & 0.000002 & 19.274 & 0.001 & 15.580 & 0.001 & 38.936 & 0.003 \\
\hline \multicolumn{11}{|l|}{ Panama-Alkaline } \\
\hline So96-1 & 0.703495 & 0.000003 & 0.512999 & 0.000003 & 19.084 & 0.001 & 15.566 & 0.001 & 38.709 & 0.002 \\
\hline CP97-1 & 0.703538 & 0.000003 & 0.512997 & 0.000003 & 19.056 & 0.001 & 15.548 & 0.000 & 38.659 & 0.002 \\
\hline M36KH & 0.703480 & 0.000002 & 0.512999 & 0.000003 & 19.081 & 0.001 & 15.574 & 0.001 & 38.726 & 0.003 \\
\hline M37KH & 0.703485 & 0.000003 & 0.513005 & 0.000002 & 19.063 & 0.002 & 15.560 & 0.002 & 38.677 & 0.005 \\
\hline M99a KH & 0.703533 & 0.000003 & 0.513006 & 0.000002 & 19.080 & 0.001 & 15.564 & 0.001 & 38.708 & 0.002 \\
\hline M105 KH & 0.703468 & 0.000003 & 0.512995 & 0.000002 & 19.075 & 0.001 & 15.569 & 0.001 & 38.716 & 0.003 \\
\hline M 118aKH & 0.703499 & 0.000003 & 0.512989 & 0.000001 & 19.062 & 0.002 & 15.568 & 0.002 & 38.708 & 0.004 \\
\hline M121aKH & 0.703516 & 0.000003 & 0.512990 & 0.000005 & 19.090 & 0.001 & 15.572 & 0.001 & 38.743 & 0.002 \\
\hline $3-12-4-03$ & 0.703540 & 0.000005 & 0.512983 & 0.000003 & 19.121 & 0.001 & 15.579 & 0.000 & 38.787 & 0.001 \\
\hline
\end{tabular}

precision step-heating ages (Table 1). The new age data suggest that there has been a migration of the alkaline activity towards the northwest in the back-arc units from southern Costa Rica towards Nicaragua at a rate of $40 \mathrm{~mm} / \mathrm{yr}$ (Fig. 1).

The oldest back-arc alkaline igneous rocks are located in the southeast Caribbean region of Costa Rica (Fig. 1). This unit is locally known as the Victoria Dike Swarm and includes a series of shallow mafic intrusions (Dengo, 1962). One of the dikes yielded an age of $6.49 \pm 0.03 \mathrm{Ma}$, which is slightly older than the age $(5.88 \pm 0.23 \mathrm{Ma})$ reported by Abratis and Wörner (2001) for another dike of this same unit.

The alkaline activity migrated towards the northwest, preserved in a series of alkaline basalt lava flows and dikes known as the Guayacan
Formation, located at the base of the Caribbean side of the active volcanic front. New ages for alkaline basalts from the Guayacan Formation, range between $4.51 \pm 0.37$ a $4.33 \pm 0.07 \mathrm{Ma}$, confirming the $4.5 \mathrm{Ma} \mathrm{K} / \mathrm{Ar}$ ages reported by Bellón and Tournón (1978) for this unit.

The next pulse of back-arc alkaline activity is preserved in a series of hills in north-south alignments, that possibly represent the remnant of eroded edifices group here in the Azules Unit. The southern-most hills are the Lomas Azules and two lavas from this location provided ages that range between $3.60 \pm 0.03$ and $3.23 \pm$ 0.03 Ma. Further north, lava collected in the Cerro Coronel provided a slightly younger age of $3.06 \pm 0.08 \mathrm{Ma}$. North of Lomas Azules, near the Costa Rican-Nicaraguan border there are a series of small isolated 
hills known as the Lomas del Colorado. The newly dated Lomas del Colorado lavas range between $3.13 \pm 0.06$ and $2.01 \pm 0.11 \mathrm{Ma}$, possibly representing the last pulse of the Azules Unit.

The northern-most dated unit is the Cukra Hill, an isolated hill made of basaltic lava flows in the Pear Lagoon area of Nicaragua. One lava flow sample from Cukra Hill yielded an age of $0.74 \pm 0.03 \mathrm{Ma}$, younger than the $\mathrm{K} / \mathrm{Ar}$ ages of $3.24 \pm 0.43$ to $1.44 \pm 0.41 \mathrm{Ma}$ reported by Janoušek et al. (2010) for the Cukra Hill/Pearl Lagoon area. The most recent volcanic activity (possibly $<<0.1 \mathrm{Ma}$ ) is represented by small cinder cones near the Caribbean coast of Costa Rica (Cerro Tortuguero) and in the Pearl Lagoon area of Nicaragua (Volcan Blue). This interpretation is based on the cone morphology, the state of preservation of the rocks (mostly fresh mafic tephra with olivine phenocrysts) in these localities and the fact that the collected samples were too young to be dated by ${ }^{40} \mathrm{Ar} /{ }^{39} \mathrm{Ar}$ techniques, yielding 0 ages in the step-heating experiments.

Alkaline lavas in Panama erupted eastward of the subducting Panama Fracture Zone (PFZ) in the fore-arc and along the volcanic front, together with adakitic volcanic centers (Fig. 1). Our new ages demonstrate a correlation between the first recorded adakites in southern Costa Rica and Panama (4.54 \pm 0.64 to $3.64 \pm 0.05 \mathrm{Ma})$ and the first pulse of alkaline volcanism in Panama $(4.45 \pm 0.35 \mathrm{Ma})$. The adakites west of the subducting PFZ show an age progression decreasing towards the southeast from $4.54 \pm 0.64 \mathrm{Ma}$ in southern Costa Rica to $0.23 \pm 0.08 \mathrm{Ma}$ in Panama (west of the PFZ), with a rate of $35 \mathrm{~mm} / \mathrm{yr}$ (Fig. 1). These new results are consistent with the work of Wegner et al. (2010) that reported the first appearance of adakitic lavas in this region of Panama $\sim 2 \mathrm{Ma}$.

\subsection{Petrography}

The main crystalline phases in the alkaline basalts are olivine, and minor clinopyroxene and plagioclase. Olivine is typically unaltered and commonly contains melt and spinel inclusions. Clinopyroxenes are mostly Ti-augites or aegirines. Plagioclase (generally high in $\mathrm{Ca}$, $\mathrm{An}>70 \%$ ) is only abundant in the shallow intrusions in the Guayacan Formation and the Victoria Dikes. The matrix is generally trachytic, composed of plagioclase, clinopyroxene, olivine, magnetite, glass and occasionally traces of biotite. In the low-silica samples $\left(\mathrm{SiO}_{2}<45 \%\right.$, Fig. 2), feldspathoids (generally analcime) are present in the matrix.
Feldspathoids (analcime and hauyne) are also common in the shallow intrusion of the Guayacan Formation together with amphibole and traces of biotite. Within the alkaline basalt units we found five new localities where the basalts contained spinel-bearing mantle peridotite and pyroxenite inclusions with reaction rims. The adakites are composed of clinopyroxene, and orthopyroxene in an interstitial matrix of plagioclase, pyroxenes and glass. Some of the adakites (trachy-andesites in Fig. 2) are also composed of amphibole and biotite with cumulates of the same minerals in a trachytic matrix.

\subsection{Major and trace elements}

This study produced 123 new major element analyses (Supplementary Materials, Table S3). The back-arc samples from Costa Rica and Nicaragua and the alkaline basalts from Panama range from picritic basalts and basanites to basaltic trachy-andesites (Fig. 2). The back-arc samples are characterized by lower $\mathrm{SiO}_{2}$ and higher alkali contents than the volcanic front lavas (Fig. 2). The adakite samples are basaltic andesites to andesites and trachy-andesites with similar major element compositions to the volcanic front lavas (Fig. 2).

We report 73 new trace element analyses in Table S4 (Supplementary Materials). The samples are plotted on primitive mantle normalized trace element diagrams in Fig. 3 and compared to OIB and arc samples from the volcanic fronts of Costa Rica and Nicaragua (Fig. 3A). The back-arc lavas in Costa Rica and Nicaragua have trace element patterns similar to OIB lavas with minor depletions in high field strength elements (HFSE, e.g., $\mathrm{Nb}$, Ta and $\mathrm{Zr}$ ) relative to the volcanic front lavas. In general the older samples Victoria Dikes ( 6.5 Ma) and Guayacan/Azules (4.5-2 Ma) (Fig. 3C and E) have more pronounced HFSE depletions than the younger $(<<0.1 \mathrm{Ma})$ samples of Tortugero and Pearl Lagoon/Cuckra Hill with flat and even positive HFSE enrichments (Fig. 3B, C and D). Based on this, Janoušek et al. (2010) sugested a subduction-free signature for the distant $(>300 \mathrm{~km}$ from the trench) Pearl Lagoon and Cuckra Hill samples.

The alkaline lavas in Panama have variable HFSE depletions relative to the primitive mantle normalization (Fig. 3D) but much less than the adakites and volcanic front lavas. Enrichments in fluid mobile elements like $\mathrm{Ba}$ and $\mathrm{Sr}$ in the overall patterns are also less evident in the younger back-arc alkaline samples. In general the back-arc lavas from Costa Rica and the alkaline lavas from Panama have $\mathrm{Pb}$ and $\mathrm{K}$

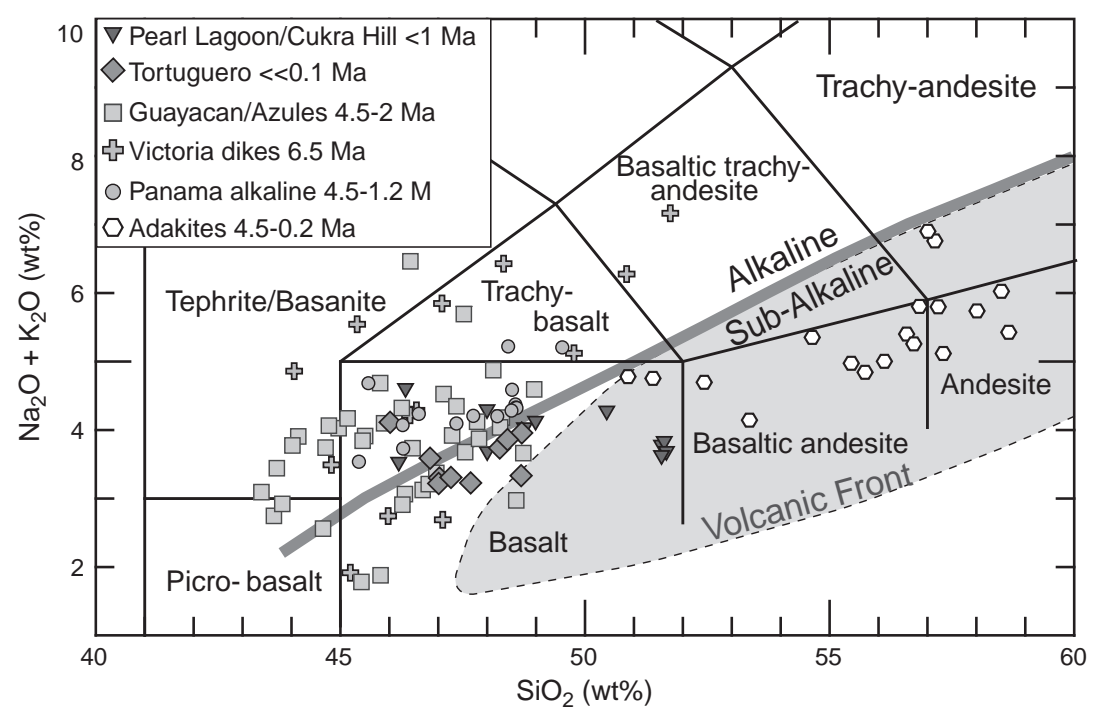

Fig. 2. Geochemical classification of the samples collected in this study compared with the volcanic front lavas from Carr et al. (2003). The back-arc samples from Costa Rica and Nicaragua and the alkaline basalts from Panama range from picritic basalts and basanites to basaltic trachy-andesites. The adakites range from basaltic andesites to andesites and trachy-andesites with compositions similar to the high-K trend of the volcanic front in central Costa Rica (Gazel et al., 2009). 

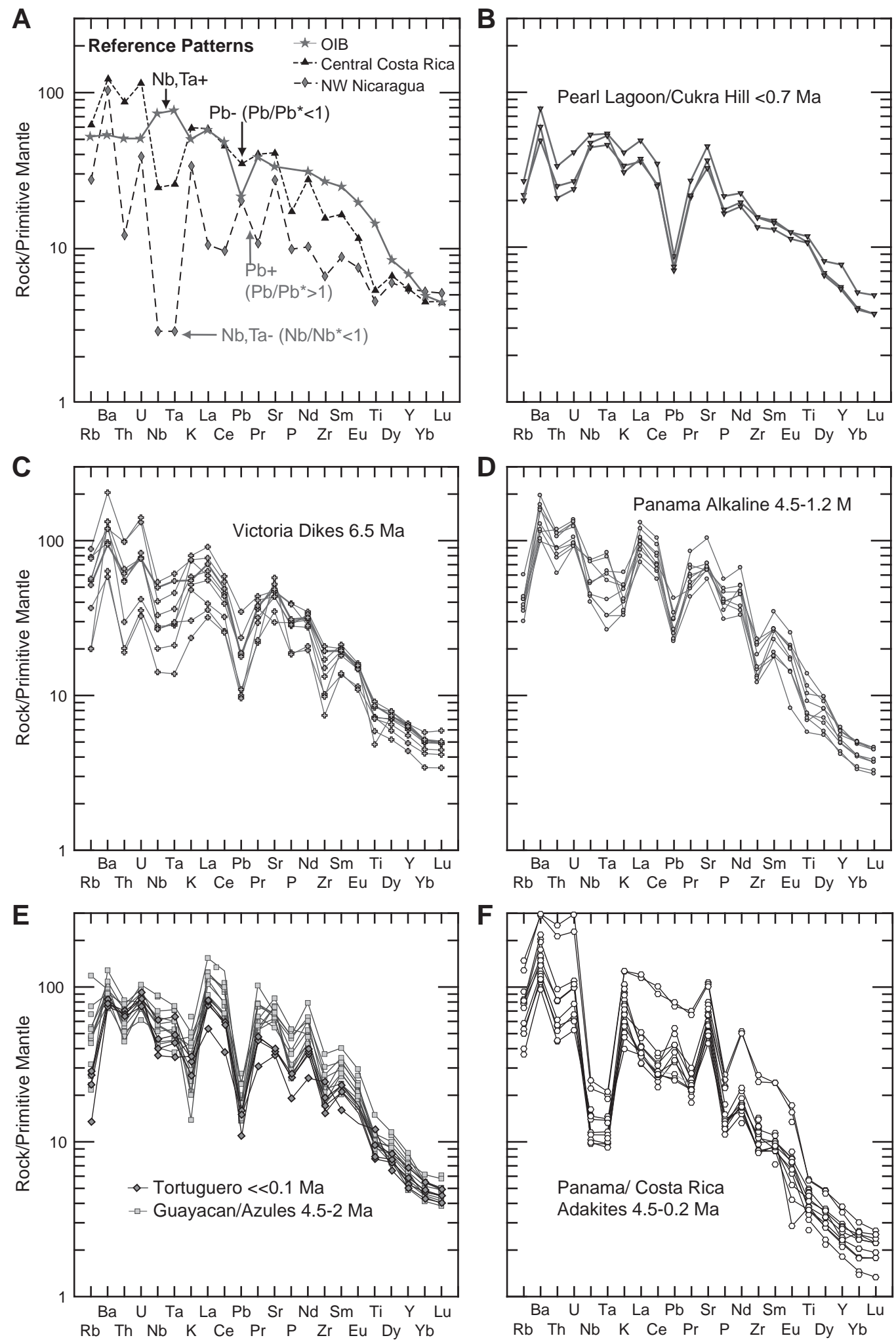

Fig. 3. Primitive mantle (McDonough and Sun, 1995) normalized multi-element diagrams. The adakites from southern Costa Rica/Panama are the only samples with the typical arctype depletions in $\mathrm{Nb}$ and $\mathrm{Ta}$ and enrichment in $\mathrm{Pb}$ (reference patterns in $\mathrm{A}$ ). In contrast, the Pearl Lagoon/Cukra Hill samples are enriched in $\mathrm{Nb}$ and $\mathrm{Ta}$ and depleted in $\mathrm{Pb}$. With the exception of enrichments for Ba and Sr, the Pearl Lagoon/Cukra Hill patterns are similar to those of typical ocean island basalt (OIB). All of the other alkaline rocks have characteristics intermediate between the subduction zone and OIB reference patterns. The adakites also have the most dramatic large ion lithophile element enrichments (e.g., Sr, Ba, U) and depletions in the heavy REE (e.g., Yb, Lu) and HSFE (e.g. Nb, Ta). The reference patterns in A for the volcanic arc from Carr et al. (2007) and the OIB reference is from Sun and McDonough (1989).

depletions, commonly observed in Galapagos-related lavas (e.g., Hoernle et al., 2000; Werner et al., 2003). On the other hand, the adakites have very strong depletions in HFSE, the heavy rare earth elements (REE) and Y, and important enrichments in fluid mobile elements like $\mathrm{Ba}, \mathrm{Pb}$, and $\mathrm{Sr}$ (Fig. 3F), consistent with the classification by Defant et al. (1992), with $\mathrm{Y}<20 \mathrm{ppm}, \mathrm{Yb}<2 \mathrm{ppm}$, and $\mathrm{Sr}>800 \mathrm{ppm}$. 


\section{4. $\mathrm{Sr}, \mathrm{Nd}$ and $\mathrm{Pb}$ radiogenic isotopes}

We report 9 new $\mathrm{Sr}-\mathrm{Nd}-\mathrm{Pb}$ radiogenic isotopes ratios and included 42 unpublished $\mathrm{Sr}$-isotopic analyses (Table 2) with the objective to better constrain the different source components of the alkaline basalts and adakites and build on data published by Hoernle et al. (2008). The most radiogenic Pb-isotopic values $\left({ }^{206} \mathrm{~Pb} /{ }^{204} \mathrm{~Pb}>19.0\right.$ and ${ }^{208} \mathrm{~Pb} /{ }^{204} \mathrm{~Pb}>38.8$ ) were found in the samples collected in the back-arc of Costa Rica and the adakites in Panama. Less radiogenic ratios $\left({ }^{206} \mathrm{~Pb} /\right.$ ${ }^{204} \mathrm{~Pb}<19.0$ and ${ }^{208} \mathrm{~Pb} /{ }^{204} \mathrm{~Pb} \sim 38.6$ ) were found in samples from the Pearl Lagoon/Cukra Hill area in Nicaragua. ${ }^{87} \mathrm{Sr} /{ }^{86} \mathrm{Sr}$ increased from 0.7031 in the Nicaraguan samples to $\sim 0.7035-0.7038$ in the Costa Rican back-arc samples and the Panamanian alkaline lavas. ${ }^{143} \mathrm{Nd} /$ ${ }^{144} \mathrm{Nd}$ decreased from 0.51305 in the Pearl Lagoon/Cukra Hill samples to 0.51295 in the Costa Rican back-arc and Panama adakite rocks.

\section{Discussion}

\subsection{Discrimination of magma source lithology}

Determining the source lithology of a suite of magmatic samples is not only important for the overall geotectonic interpretation of the magma genesis, but it is also crucial to petrological modeling based on parameterization of experimental data and observations made on mantle peridotite sources. In recent years, the development of new petrological methods based on major element geochemistry (e.g., Sobolev et al., 2005; Herzberg and Asimow, 2008; Dasgupta et al., 2007) provided new insights for the composition of magma source lithology.

From the suite of lavas collected for this study there is a population of low-silica $\left(<45 \% \mathrm{SiO}_{2}\right)$ samples characterized by high $\mathrm{CaO}$ contents, similar to experimental melts produced from a $\mathrm{CO}_{2}$-metasomatized peridotite (Dasgupta et al., 2007) (Fig. 4A). There is also a minor population of samples (generally the sub-alkaline lavas, Fig. 2) with lower $\mathrm{CaO}$ and higher $\mathrm{SiO}_{2}$ contents (Fig. 4A), which have modeled liquid lines of descent (Fig. 4A) that suggest that these samples are not the result of normal fractional crystallization of a peridotite source primary magma. Therefore, in order to explain their geochemistry, these samples required to be (a) derived from a pyroxenite component (Fig. 4A) or (b) generated by large amounts of highpressure pyroxene fractionation in the mantle (Albarède et al., 1997; Herzberg and Asimow, 2008). More detailed work (e.g. analyses of olivine compositions) is required to determine if there is a pyroxenitic component in the source of these lavas. For now, we can infer that if there is a pyroxenitic component it may be in the form of veins that result from the reaction of silica-rich melts with a mantle peridotite (Feigenson and Carr, 1993; Sobolev et al., 2005; Herzberg, 2006).

The adakite samples fall on the high-K trend of the volcanic front lavas from central Costa Rica that have been interpreted to be the result of mantle metasomatism by slab derived melts (Hoernle et al., 2008; Gazel et al., 2009). The relatively higher adakite samples have compositions close to experimental eclogite melts (Pertermann and Hirschmann, 2003) (Fig. 4A). According to Martin et al. (2005), the adakites collected in Costa Rica and Panama data belong to the lowsilica $\left(\mathrm{SiO}_{2}<60 \%\right.$, Fig. $\left.4 \mathrm{~A}\right)$ type. This adakite type is interpreted as magmas produced from a mantle wedge metasomatized by silicic melts from the subducting slab.

It has also been argued that the source lithology of some alkaline and high Nb-basalt could be amphibole-bearing veins or cumulates located in the lithospheric mantle (Defant et al., 1992; Médard et al., 2006; Pilet et al., 2008a,b). Some of alkaline basalts (generally the same samples with low $\mathrm{SiO}_{2}$ and high $\mathrm{CaO}$ in Fig. 4A) overlap with the low pressure experiments of melts produced by an amphibolebearing source (Fig. 4B). Nevertheless, most of the samples are more consistent with an amphibole-free peridotite or pyroxenite source (Fig. 4A).
5.2. Geochemical variations between the volcanic front and the back-arc: slab signature vs. mantle control

It is widely accepted that the magmatic production in a volcanic arc results from the partial melting of the mantle wedge triggered by fluids from the subducted slab. Along the volcanic front in Central America the geochemical indicators of subducting sediments (e.g. Ba/ La, U/Th and ${ }^{10} \mathrm{Be} /{ }^{9} \mathrm{Be}$ ) define a maximum in northwest to central Nicaragua and a minimum in central Costa Rica (Carr et al., 1990; Leeman et al., 1994; Patino et al., 2000).

Feigenson and Carr (1993) proposed two mantle reservoirs for Central America. The most common reservoir is analogous to depleted mantle (DM). The second reservoir has a more enriched composition and is thought to be composed of garnet-bearing pyroxenitic veins within a DM reservoir. Melting of this veined mantle, triggered by input of subduction fluids, produces magmas with a typical arc signature in most of the volcanic front (Carr et al., 2003; Feigenson et al., 2004). However, central Costa Rican lavas have an anomalous OIB-like geochemical signature, common in intraplate settings (Reagan and Gill, 1989; Herrstrom et al., 1995; Gazel, 2003; Feigenson et al., 2004; Hoernle et al., 2008; Gazel et al., 2009).

The OIB signature of the volcanic front in central Costa Rica is characterized by the steep REE patterns $(\mathrm{La} / \mathrm{Yb}>10)$ of the erupted lavas (Carr et al., 1990). Higher La/Yb indicates a lower degree of partial melting or derivation from a more enriched source. The overall correlation between $\mathrm{La} / \mathrm{Yb}$ and radiogenic isotope ratios indicates that a more enriched source is present with higher La/Yb ratios beneath central Costa Rica and Panama volcanic front (Gazel et al., 2009).

Plots of distance along the volcanic front vs. ${ }^{206} \mathrm{~Pb} /{ }^{204} \mathrm{~Pb}$ and $\mathrm{La} / \mathrm{Yb}$ values from the adakites and alkaline basalts (Fig. 5A and B) reveal similar correlations than the ones described for the volcanic front (e.g. Carr et al., 1990, 2007). The lowest ${ }^{206} \mathrm{~Pb} /{ }^{204} \mathrm{~Pb}$ and $\mathrm{La} / \mathrm{Yb}$ are in the Nicaraguan samples and the highest ${ }^{206} \mathrm{~Pb} /{ }^{204} \mathrm{~Pb}$ and $\mathrm{La} / \mathrm{Yb}$ are in Costa Rica and Panama (Fig. 5A and B). Therefore, the geochemical variations along the arc reflect regional changes in the extent and type of metasomatic processes caused by the subducting input and magma source composition and not just the degree of partial melting as suggested by Gazel et al. (2009).

Fractionation of HFSE (e.g., Nb, Ta, Zr, Ti, Hf) relative to the large ion lithophile and light rare earth elements is well known for convergent margin igneous rocks (e.g. the northwest Nicaragua and central Costa Rica arcs patterns in Fig. 3A). This fractionation is related to subduction processes in which a residual mineral phase in the subducting slab (rutile) or mantle wedge (amphibole) holds the HFSE (e.g., Ringwood, 1990; Foley et al., 2000, 2002). The Nb/Nb* denotes the variations in the typical arc depletion of $\mathrm{Nb}$ relative to $\mathrm{U}$ and $\mathrm{La}$, when normalized to the McDonough and Sun (1995) primitive mantle reference. Magmas produced in a subduction zone will have $\mathrm{Nb} / \mathrm{Nb}^{*}<1$, whereas magmas produced by mantle upwelling (decompression melting) with no subduction signature (intraplate settings) are characterized by $\mathrm{Nb} / \mathrm{Nb}^{*}>1$. The volcanic front lavas of Costa Rica and Nicaragua and the adakites from Panama have significant subduction signature with $\mathrm{Nb} / \mathrm{Nb}^{*}<0.5$ (Fig. 5C). Conversely, the backarc lavas in Nicaragua (Pearl Lagoon/Cukra Hill) have positive Nb and Ta anomalies (Fig. 3B), which is reflected in $\mathrm{Nb} / \mathrm{Nb}^{*}>1$ (Fig. 5C). Alkaline basalts in Panama and back-arc lavas from Costa Rica have transitional $\mathrm{Nb} / \mathrm{Nb}^{*}(0.5-1)$. This suggests that these lavas were produced by mantle upwelling, but with some influence of components.

HFSE depletions $\left(\mathrm{Nb} / \mathrm{Nb}^{*}<0.5\right.$, Fig. $\left.5 \mathrm{C}\right)$ are restricted to geographic locations directly above the subducting Cocos slab as inferred from the seismic studies (see contours in Fig. 1). HFSE depletions are common in the volcanic front of Costa Rica, in the volcanic front lavas of Nicaragua and the adakites in southern Costa Rica/Panama (Figs. 4 and 5C). In contrast, samples with $\mathrm{Nb} / \mathrm{Nb}^{*}>0.5$ are located in areas with no clear seismic evidence of a subducting slab (Panama) or well-behind it in the back-arc regions of Costa Rica and Nicaragua. These spatial-geochemical 
A

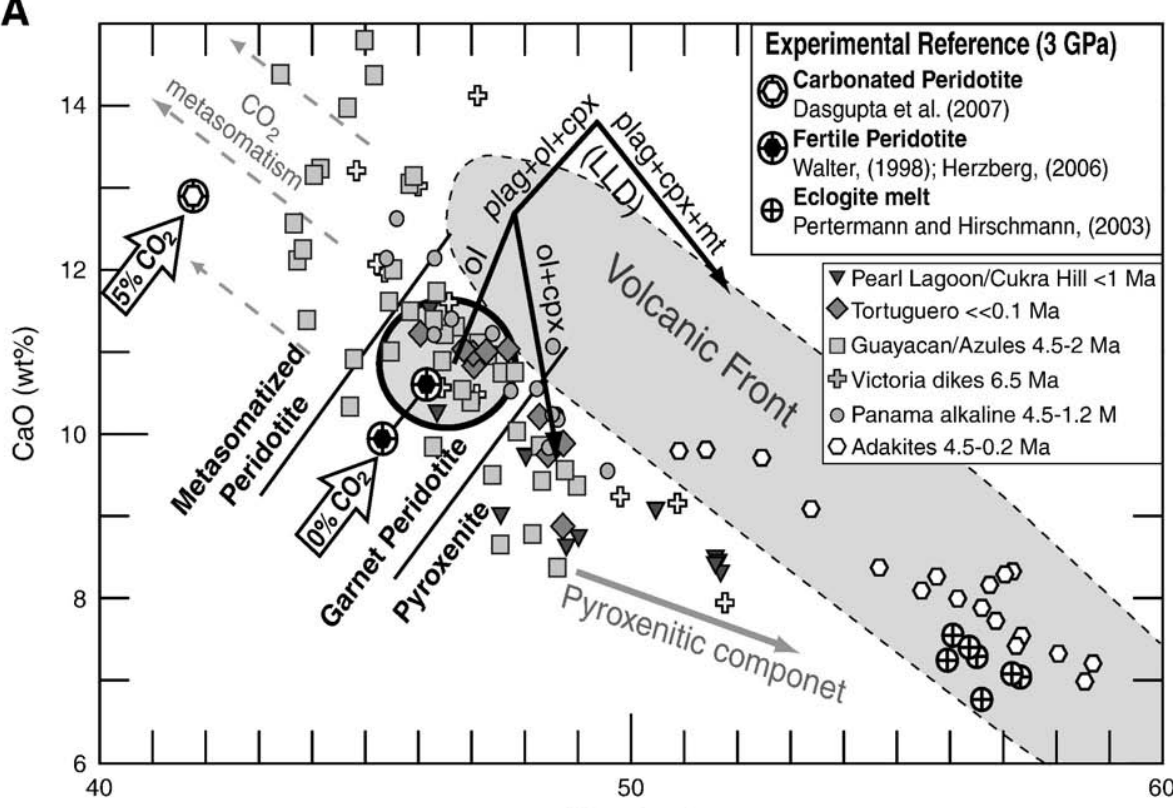

$\mathrm{SiO}_{2}(\mathrm{wt} \%)$

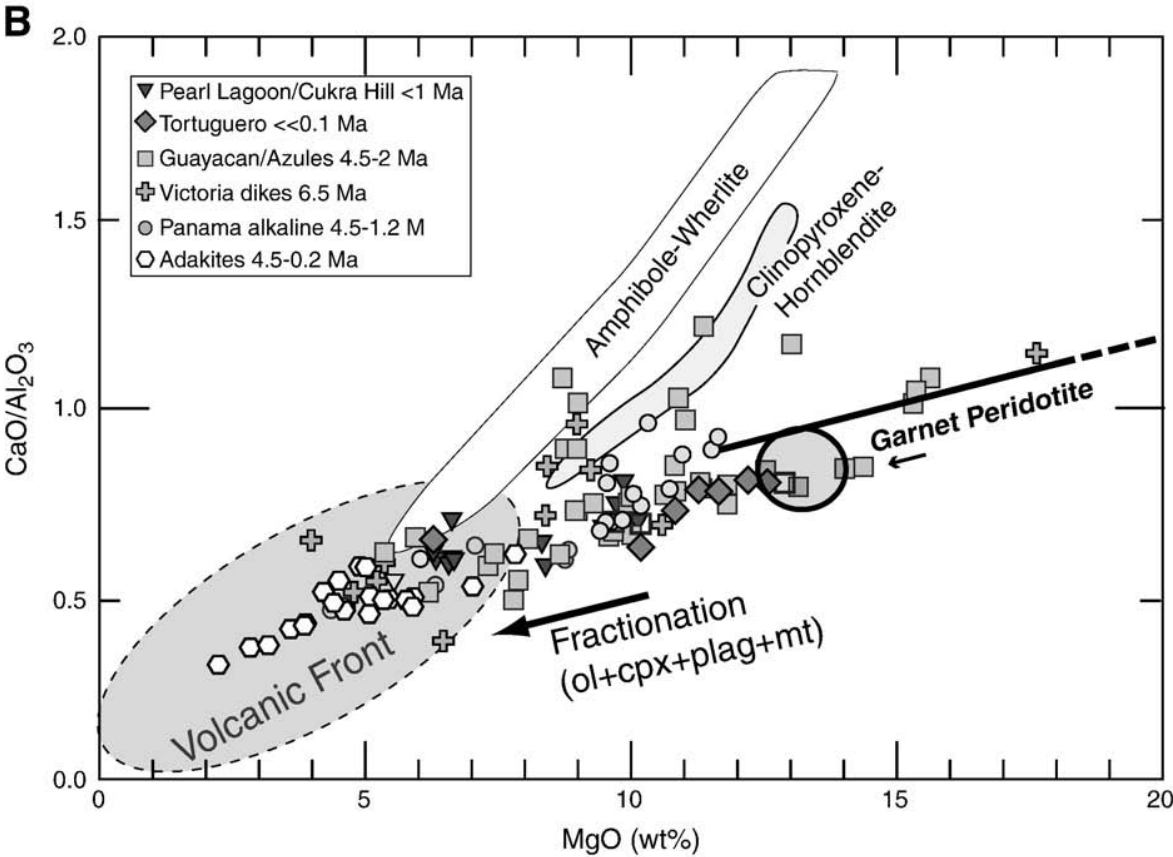

Fig. 4. Possible source lithologies and the effect of fractional crystallization for the samples collected in this study. A) Petrological discrimination of magma sources for primary magmas produced in the garnet stability field ( $3 \mathrm{GPa})$ modified from Herzberg and Asimow (2008). The two diagonal lines separate magmas melted from metasomatized (carbonated) peridotite, garnet peridotite and pyroxenite. The low-silica $\left(<45 \% \mathrm{SiO}_{2}\right)$ samples are characterized by high $\mathrm{CaO}$ contents, similar to experimental compositions of magmas produced by melting a carbonated peridotite. The population with lower $\mathrm{CaO}$ and higher $\mathrm{SiO}_{2}(>47 \%$ ) shows similar compositions to magmas produced by melting second stage pyroxenite or derivative liquids of high-pressure pyroxene fractionation. The adakites with relative higher $\mathrm{SiO}_{2}(>55 \%)$ have compositions similar to experimental eclogite melts. The liquid line of descent (LLD) of a representative primary magma was modeled using Petrolog Software. B) The alkaline basalt, adakites and volcanic front (Carr et al., 2003) samples are compared to two low pressure (<1 GPa) experimental melting trends, amphibole-bearing wherlite (Médard et al., 2006) and clinopyroxene bearing hornblendite (Pilet et al., 2008a,b) and to primary garnet lherzolite melts modeled in this study (Table 3). Some of the low pressure melting experiments overlap the alkaline basalt array at high CaO/ $\mathrm{Al}_{2} \mathrm{O}_{3}$ suggesting that hornblende bearing metasomatic veins (reaction between slab derived melts and peridotite in the lithosphere) could be the source of some of the alkaline magmas. The experimental data was filtered to results with $\mathrm{SiO}_{2}$ compositions in range with the alkaline samples included in this study.

correlations are consistent with the HFSE depletions in the arc magmatism being controlled by the presence of a HFSE retaining phase (e.g. residual rutile) in the subducting slab.

Magmas produced by arc volcanism are also characterized by having enrichments in fluid mobile elements (e.g., Ba, K, Pb, Sr) relative to other trace elements. In contrast, the behavior of fluid mobile elements is the opposite in OIB magmas (see reference patterns in Fig. 3A). Previous studies showed that the $\mathrm{Pb}$ concentra- tions and $\mathrm{Pb}$ isotope systematics in the Central American volcanic front are largely controlled by the interaction between the subducting oceanic crust and the mantle (Feigenson et al., 2004; Hoernle et al., 2008; Gazel et al., 2009). Based on these studies, we follow a similar approach to the one previously discussed for $\mathrm{Nb}$, but with $\mathrm{Pb}$. The $\mathrm{Pb} /$ $\mathrm{Pb}^{*}$ indicates the concentrations of $\mathrm{Pb}$ relative to $\mathrm{Ce}$ and $\mathrm{Pr}$ normalized to a primitive mantle reference. $\mathrm{Pb} / \mathrm{Pb}^{*}>1$ indicates positive $\mathrm{Pb}$ anomalies typical of arc magmatism, whereas $\mathrm{Pb} / \mathrm{Pb}^{*}<0.5$ indicates a 

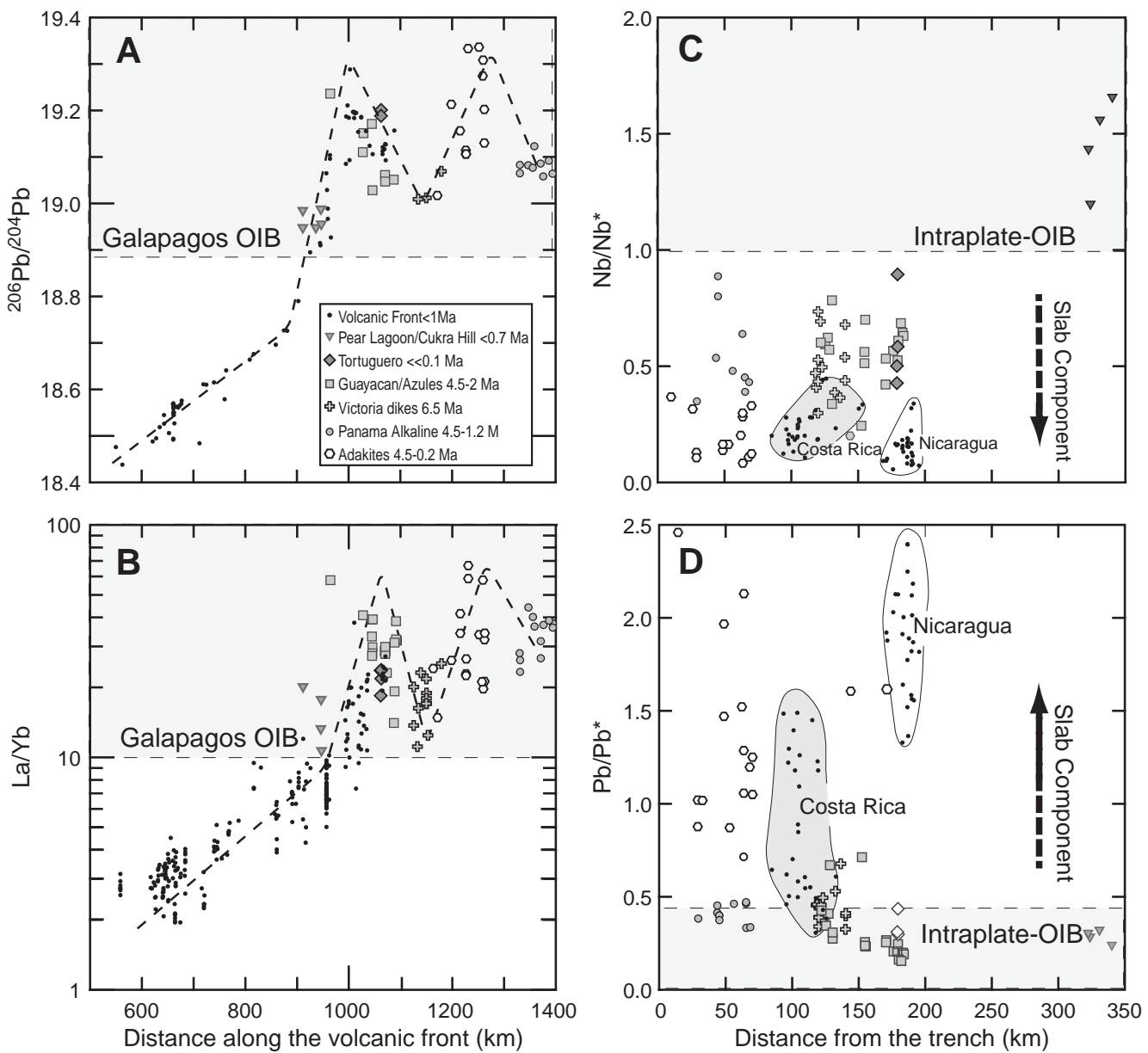

Fig. 5. Pb isotope and trace element variations along the volcanic front from Nicaragua to western Panama (A and B) and across (B and C) the arc in southern Central America. The left panel shows similar variations in ${ }^{206} \mathrm{~Pb} /{ }^{204} \mathrm{~Pb}$ and $\mathrm{La} / \mathrm{Yb}$ with distance along the volcanic front. The HFSE depletions and Pb enrichments (Fig. $3 \mathrm{~A}$ ) typical of an arc setting were evaluated across the subduction system. Magmas produced with a significant subducting slab component will have $\mathrm{Nb} / \mathrm{Nb}^{*}<1$, magmas with evident $\mathrm{Nb}$ depletions will have values $\mathrm{Nb} / \mathrm{Nb}^{*}<0.5$ and magmas produced by mantle upwelling with no/minor subduction signature will have $\mathrm{Nb} / \mathrm{Nb}^{*}>1$. $\mathrm{Pb} / \mathrm{Pb}{ }^{*}>1$ indicate positive $\mathrm{Pb}$ anomalies typical of arc magmatism (Fig. $3 \mathrm{~A}$ reference patterns for the volcanic front) and $\mathrm{Pb} / \mathrm{Pb}^{*}<0.5$ indicates a depleted $\mathrm{Pb}$ signature that is typical of intraplate (OIB reference pattern in Fig. $3 \mathrm{~A}$ ) magmatism. Intermediate $\mathrm{Pb} / \mathrm{Pb}^{*}(0.5-0.1)$ indicate a combination between arc and intraplate processes. The Galapagos OIB range is from the GEOROC database (http://georoc. mpch-mainz.gwdg.de) and the volcanic front data are from Carr et al. (2003) and Hoernle et al. (2008).

relative depleted $\mathrm{Pb}$ signature that is typical of intraplate (OIB-type) magmatism. Intermediate $\mathrm{Pb} / \mathrm{Pb}^{*}(0.5-0.1)$ indicates a combination of arc and intraplate (mantle upwelling) processes. Figs. 1 and 5D show that there is also a direct correlation between $\mathrm{Pb} / \mathrm{Pb}^{*}>1$ and the presence of the subducting slab inferred from seismic studies. The volcanic front from Nicaragua, most of the Costa Rican volcanic front and the adakites in southern Costa Rica/Panama have $\mathrm{Pb} / \mathrm{Pb}^{*}>1$ controlled by $\mathrm{Pb}$ addition from the subducting slab (Fig. 5D). On the other hand, most of the alkaline lavas in Panama and the back-arc lavas of Costa Rica and Nicaragua have major depletions in $\mathrm{Pb}(\mathrm{Pb} /$ $\mathrm{Pb}^{*}<0.5$ ) (Fig. 5D). These samples are interpreted to be the result of mantle upwelling processes, analogous to an OIB intraplate setting. However, a limited number of back-arc samples and the central Costa Rican volcanic front samples show transitional $\mathrm{Pb} / \mathrm{Pb}^{*}$ values, which again indicate mixing between slab derived melts and decompression melts by mantle upwelling (Fig. 5D).

In summary, the correlation between $\mathrm{La} / \mathrm{Yb}, \mathrm{Pb}$ isotopes, $\mathrm{Nd} / \mathrm{Nd}^{*}$ and $\mathrm{Pb} / \mathrm{Pb}^{*}$ for the different arc segments suggests that these geochemical variations, both in the volcanic front and in the backarc, are controlled by the composition of the magma sources (mantle source and subducting oceanic crust components). The geochemical variations of the magmas across the arc depend on the absence of, or distance from, the subducting slab. The alkaline basalts are restricted to areas that have no clear seismic evidence of a subducting slab
(Fig. 1) and have geochemical signatures mostly controlled by decompression melting (mantle upwelling) with some contributions from the slab. The adakites are located on the edge of the subducting slab between Costa Rica and Panama and have an important slab signature. The subduction signature is, of course, also evident in the volcanic front in Costa Rica and Nicaragua.

\subsection{Fingerprinting the magma components: evidence from radiogenic} isotopes

Radiogenic isotopic ratios are robust tracers of magma components because they are not fractionated by magmatic processes such as partial melting and fractional crystallization. Therefore, they have been an important tool in the study of the source composition of Central American lavas. Previous studies show systematic regional variations in the composition of volcanic front lavas related to a chemically heterogeneous mantle composition, the nature of the overriding lithosphere, and the different subducting input components (sediments and subducting oceanic crust) (Feigenson and Carr, 1986; Reagan and Gill, 1989; Feigenson et al., 2004; Hoernle et al., 2008; Gazel et al., 2009).

$\mathrm{The} \mathrm{Pb}, \mathrm{Nd}$ and $\mathrm{Sr}$ isotope ratios collected from samples from the back-arc area of Costa Rica and Nicaragua and the adakites and alkaline basalts from southern Costa Rica and Panama, together with isotopic end-members of the subducting Galapagos seamounts/ridges 

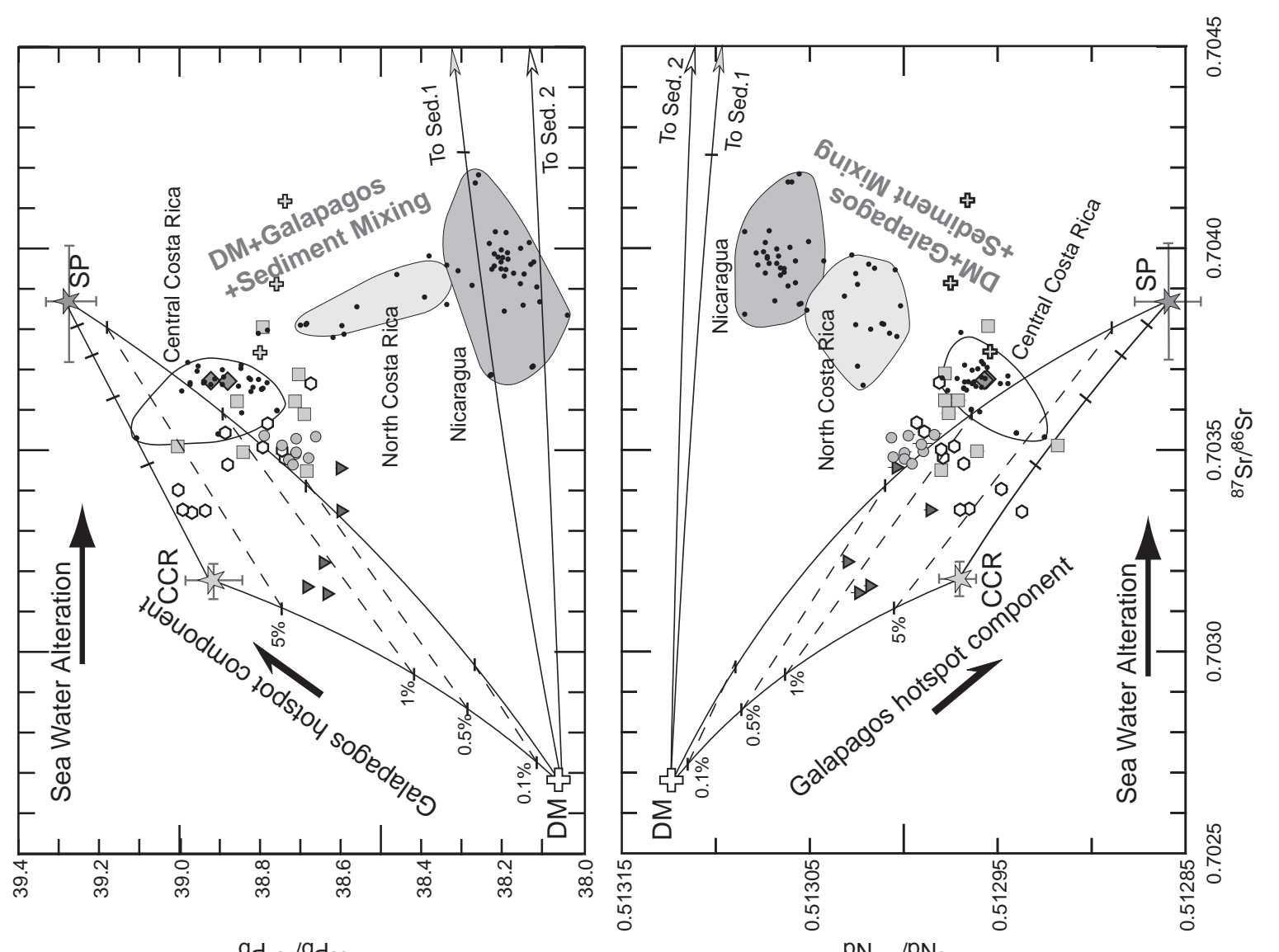

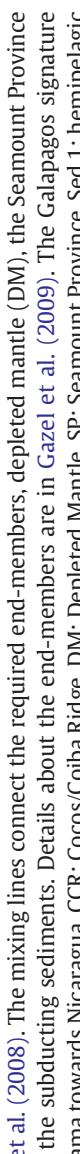

$9 d_{t 0 z} / 9 d_{80 z}$

$\mathrm{PN}_{t t l} / \mathrm{PN}_{\varepsilon t t}$

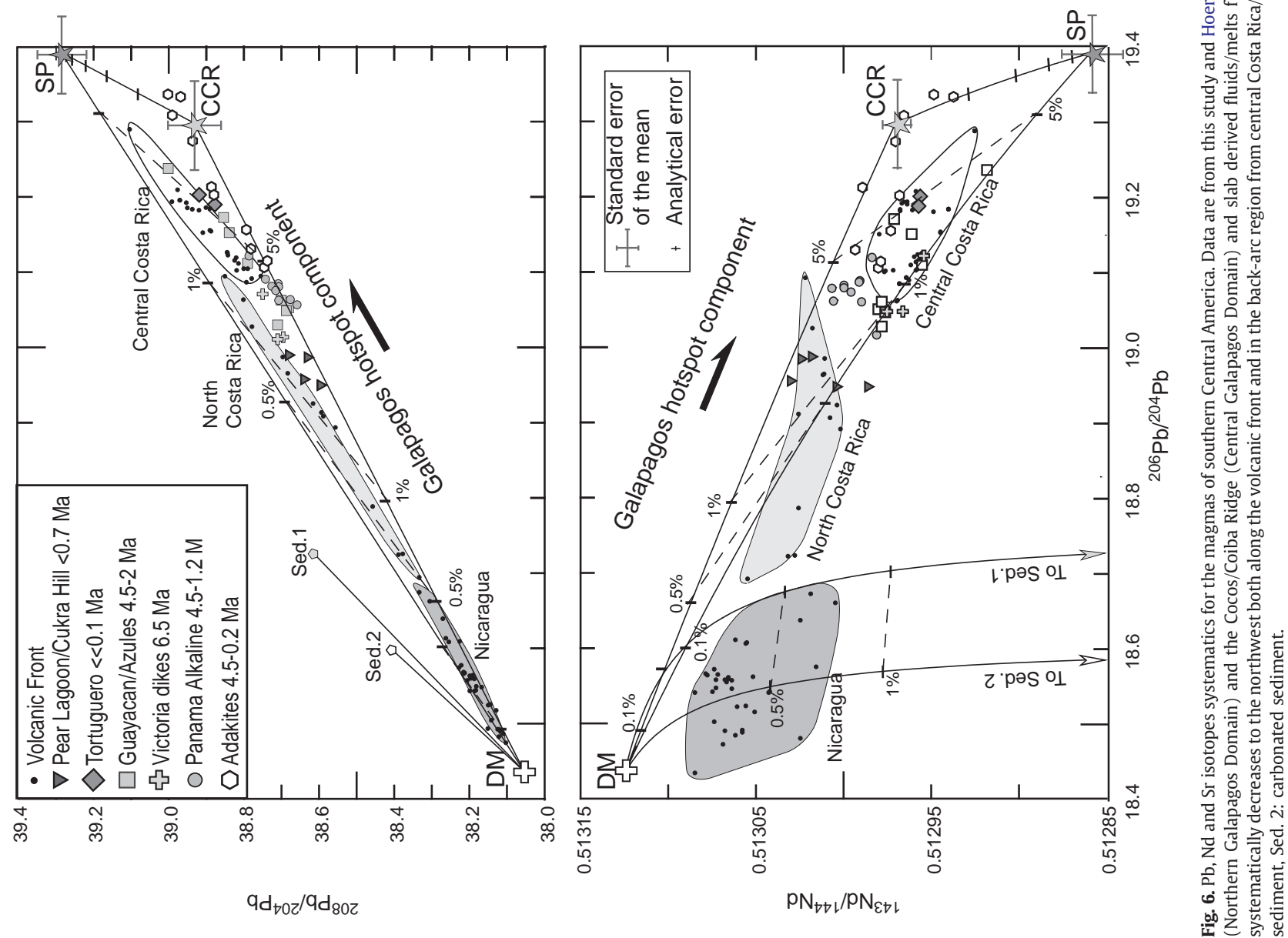


(Seamount Province and Cocos/Coiba Ridge) and subducting sediments are plotted in Fig. 6. The decrease in the Galapagos Plume components described in the volcanic front (Hoernle et al., 2008; Gazel et al., 2009) from Panama/Costa Rica towards Nicaragua is also present in the back-arc region in all the systems reported in Fig. 6. The highest $\mathrm{Pb}$ isotope, lowest $\mathrm{Nd}$ isotope and $\mathrm{Sr}$ isotope ratios are present in the Panamanian adakites and central Costa Rican volcanic front and back-arc lavas (Fig. 6).

Three isotopic end-members are required to explain the $\mathrm{Pb}$ isotopic composition of southern Central American lavas, a depleted component (either depleted mantle - DM - in the mantle wedge or depleted subducting ocean lithosphere) and two enriched components, the subducting Seamount Province and the Cocos/Coiba Ridge (Galapagos Hostpot tracks) (Hoernle et al., 2008; Gazel et al., 2009) (Fig. 6). The isotopic end-members from the Seamount Province and Cocos/Coiba Ridge were originally interpreted to be melts from the subducting slab (Hoernle et al., 2008; Gazel et al., 2009). All the evidence suggests that the Seamount Province component is a recent ( $6.5 \mathrm{Ma})$ recycled component from the subducting Galapagos tracks in front of Costa Rica (Gazel et al., 2009). Melts from this component produced the metasomatic enrichment of the mantle wedge and possibly also the lithospheric mantle in central Costa Rica. The adakites in Panama/Costa Rica are the result of the reaction of melts from the subducting Cocos and Coiba ridges with the mantle wedge, also resulting in a metasomatic enrichment of the mantle wedge and the lithosphere. As mentioned before, most of the alkaline basalts from Panama and the back-arc lavas from Costa Rica and Nicaragua were produced by mantle upwelling with some subduction contribution (Fig. 5C and D), this interpretation is also consistent with the radiogenic isotopes (Fig. 6). The $\mathrm{Sr}$ isotope ratios confirm that there are slab derived components (probably fluids/melts from the subducting sediments and altered oceanic crust) in some of the back-arc lavas from Costa Rica and the alkaline lavas of Panama (Fig. 6).

5.4. Petrological information from peridotite source primary magmas from the alkaline basalts

A primary magma is a silicate liquid that initially separates from a mantle source. In most cases primary magmas are modified by crystallization during transport to the surface and eruption (e.g., O'Hara, 1968). To reconstruct a primary magma composition, it is necessary to find the most magnesian liquids that can be identified in a given rock suite on an olivine control trend. Once the composition of a primary magma is obtained (see Appendix A for details) we can use that composition to infer petrological information such as mantle potential temperatures $\left(\mathrm{T}_{\mathrm{p}}\right)$, melt fractions and melting pressures. In an arc setting, it is a major task to obtain samples primitive enough for primary magma calculations because most rocks are too fractionated. However, we obtained 18 successful primary magma solutions through vigorous sampling and selection of olivine-phyric basalt collected from the alkaline suites of Nicaragua (1), Costa Rica (15) and Panama (2) (Table 3) using PRIMELT2 (Herzberg and Asimow, 2008).

The $\mathrm{MgO}$ content of a volatile-deficient primary magma from a peridotite source positively correlates with the temperature of the mantle source (e.g., Langmuir et al., 1992; Putirka, 2005; Herzberg et al., 2007; Herzberg and Asimow, 2008) and provides a petrological record of the mantle $T_{P}$. $T_{P}$ defines the temperature that a mass of mantle will obtain if it rises adiabatically without melting to the surface of the Earth (McKenzie and Bickle, 1988). From a primary magma composition (Table 3 ) we can determine if a primary magma is derived from a normal ambient mantle with $\mathrm{T}_{\mathrm{p}} 1350 \pm 50{ }^{\circ} \mathrm{C}$ (e.g., McKenzie et al., 2005) typical of the mid-ocean ridge system, or from a restricted mantle thermal anomaly like a mantle plume with $\mathrm{T}_{\mathrm{P}}>1500^{\circ} \mathrm{C}$ (Putirka, 2005; Herzberg and Asimow, 2008).

The $\mathrm{T}_{\mathrm{P}}$ calculated from the alkaline basalts in Nicaragua, Costa Rica and Panama, range between $\sim 1380$ and $1450{ }^{\circ} \mathrm{C}$. These $T_{\mathrm{P}}$ estimates

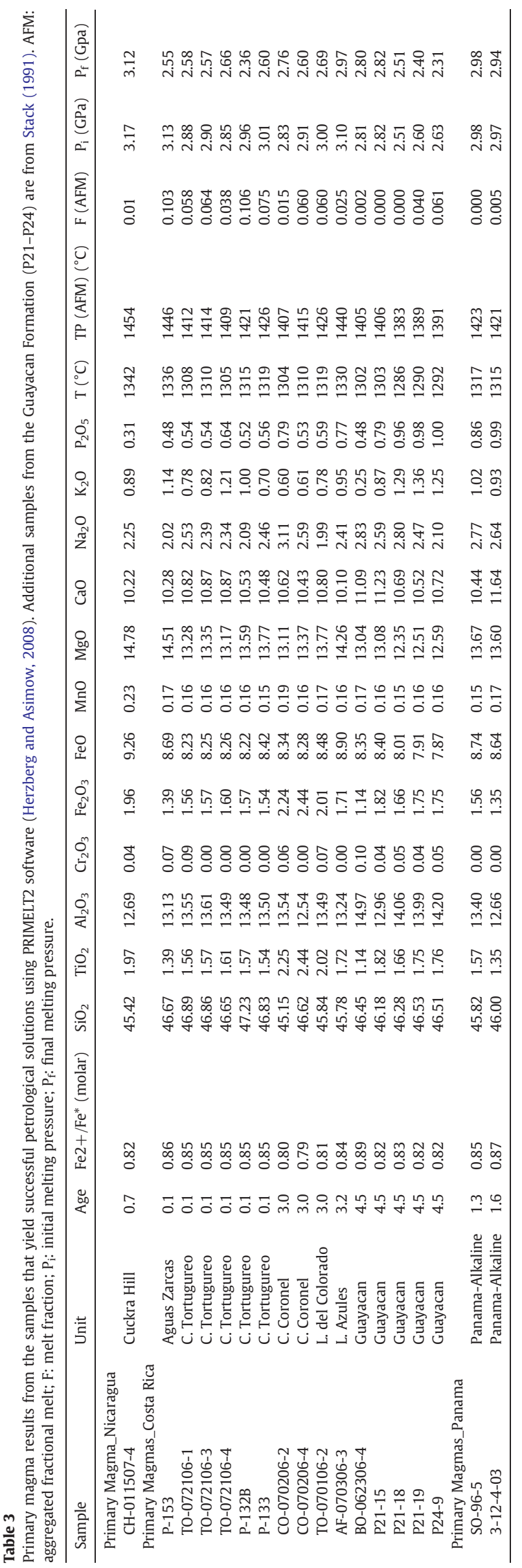




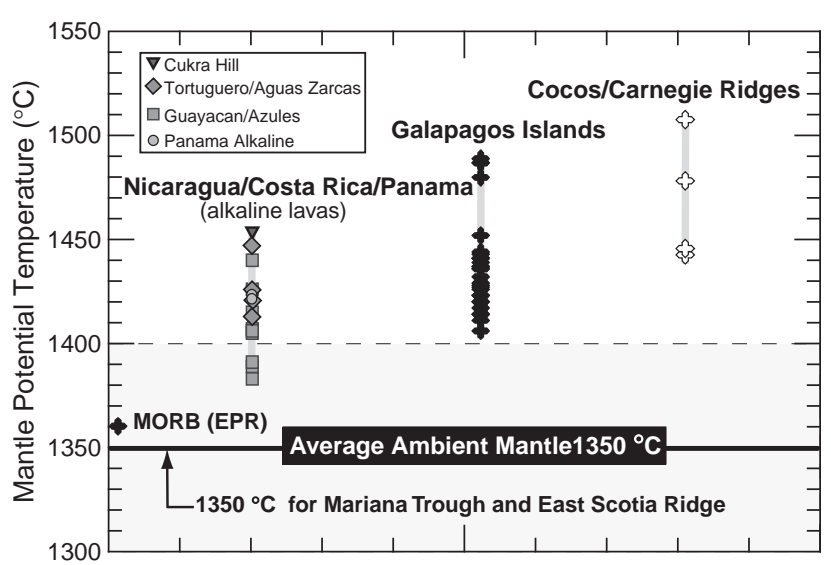

Fig. 7. Mantle potential temperatures $\left(T_{P}\right)$ for the primary magmas from the alkaline lavas of Nicaragua, Costa Rica and Panama compared to other $\left(\mathrm{T}_{\mathrm{P}}\right)$ calculations from Galapagos-related lavas from the Galapagos islands and the Cocos and Carnegie ridges (Galapagos tracks) from Herzberg and Gazel (2009). Also, $T_{P}$ estimates from other island arcs, the Mariana Trough and East Scotia Ridge (Wiens et al., 2006; Kelley et al., 2006), and the East Pacific Rise MORB (Herzberg et al., 2007) are reported for comparison. Continental arcs $T_{P}$ estimates are excluded because of different tectonic setting and the use of fractionated samples in the calculations.

are relatively higher than ambient mantle temperatures $\left(T_{\mathrm{P}} 1350 \pm\right.$ $50^{\circ} \mathrm{C}$ ) (Fig. 7). If we compare our new computed $\mathrm{T}_{\mathrm{P}}$ results with other lavas with a Galapagos Plume signature (Fig. 7), the new estimates for the alkaline basalts in Nicaragua, Costa Rica and Panama are close to those determined for the Galapagos islands and close to the $T_{P}$ calculated for the Cocos and Carnegie ridges (Galapagos tracks) (Fig. 7) (Herzberg and Gazel, 2009).

Even though Wiens et al. (2006) and Kelley et al. (2006) used a different method for $T_{P}$ calculations, they also reported mantle potential temperatures higher than ambient mantle of $1430{ }^{\circ} \mathrm{C}$ in the North Fiji Basin, $1450{ }^{\circ} \mathrm{C}$ in the Lau Basin and $1500{ }^{\circ} \mathrm{C}$ in the Manus Basin. The high $\mathrm{T}_{\mathrm{P}}$ in the Manus Basin is consistent with high ${ }^{3} \mathrm{He} /{ }^{4} \mathrm{He}$ and geophysical evidence of mantle plume activity below this basin (Macpherson et al., 1998). In the case of the Lau Basin the authors interpreted the higher $\mathrm{T}_{\mathrm{P}}$ as the result of the influx of the Samoa Plume into the mantle wedge of the Tonga Arc. The process that controls the relative high $\mathrm{T}_{\mathrm{p}}$ in the North Fiji Basin is still unknown. In contrast, the calculated $\mathrm{T}_{\mathrm{P}}$ from areas away from mantle plume activity, like Mariana Trough and the East Scotia Ridge, are expected ambient mantle $\mathrm{T}_{\mathrm{P} S}$ of $\sim 1350^{\circ} \mathrm{C}$ (Wiens et al., 2006).

We calculated the initial and final melting pressures of the primary magmas of the alkaline basalts using the geobarometer for initial melting pressure $\left(\mathrm{P}_{\mathrm{i}}\right)$ described in Appendix A. The initial melting pressures for the units that yield successful petrological solutions (Table 3) range between $\sim 3.0$ and $2.6 \mathrm{GPa}$, lying at garnet stability pressures. The final melting pressures range between $\sim 3.0$ and $2.5 \mathrm{GPa}$, from garnet stability to the garnet-spinel transition pressures. The length of the melting column, and thus the melt productivity, is controlled by a boundary that on average varies between $\sim 90$ and $85 \mathrm{~km}(\sim 2.7-2.5 \mathrm{GPa})$. This upper limit of the melting column is interpreted as the lithosphere-asthenosphere boundary (Fig. 8A and B). The calculated results agree with estimates of the lithosphere-asthenosphere boundary from recent geophysical studies that yield an average lithosphere thickness of $\sim 80 \mathrm{~km}$ for tectonically altered regions (Rychert and Shearer, 2009).

The calculated melting pressures are also consistent with the mineralogy of mantle peridotite xenoliths hosted in the back-arc alkaline basalts. The presence of spinel, as an aluminum phase instead of garnet or plagioclase, suggests that the alkaline melts generated at $\sim 100 \mathrm{~km}(\sim 3 \mathrm{GPa})$ incorporated xenoliths from the overlying lithospheric mantle ( 85-50 km) (Herzberg and Gasparik, 1991) during transport to the surface (Fig. $8 \mathrm{~A}$ and $\mathrm{B}$ ).

\subsection{Subduction-plume interaction: an intergraded geodynamic model}

The geologic record shows that alkaline lavas, adakites and volcanic front lavas with a clear Galapagos signature outcrop in Costa Rica for the first time at $\sim 6.5 \mathrm{Ma}$ (Gazel et al., 2009). Major element compositions suggest that most of the alkaline lavas in Costa Rica and Panama are derived from a mantle peridotite source. The adakites, on the other hand, are consistent with magmas from the mantle wedge metasomatized by melts from subducting slab. The geochemical signature of the adakites is also consistent with the petrologic interpretation, because they have all the common geochemical indicators (e.g., steep REE, high $\mathrm{La} / \mathrm{Yb}$ and $\mathrm{Sr} / \mathrm{Y}$ ) that suggest highpressure melting of a mafic protolith (e.g., Kay, 1978; Defant and Drummond, 1990). The upper mantle-like oxygen isotope ratios of the adakites in Costa Rica and Panama also support this interpretation (Bindeman et al., 2005). Slab melt in this part of the arc can be explained by melting of relatively young (13.0-14.5 Ma, Werner et al., 1999) subducting Galapagos Hotspot tracks in a hot mantle regime.

The petrology and geochemistry of the alkaline basalts in southern Central America suggest that they are primarily derived through mantle decompression melting and in some cases the interaction of those melts with a subduction-metasomatized lithosphere (pyroxenitic veins?). The alkaline lavas are restricted to areas where the seismic evidence indicates that there is no subducting slab while contemporaneous adakites, appear to be restricted to the area above the subducting PFZ. Tectonic reconstructions suggest that the PFZ has been migrating towards the southeast (Meschede et al., 1998; MacMillan et al., 2004). According to DeMets (2001) the plate geometry requires a southeastward progression of the triple junction because the PFZ strikes north and the convergence direction is N25E at a rate of $90 \mathrm{~mm} / \mathrm{yr}$. Therefore, the east migration of the triple junction/PFZ is $\sim 37 \mathrm{~mm} / \mathrm{yr}$ consistent with the adakites age progression of $35 \mathrm{~mm} / \mathrm{yr}$ reported here (Fig. 1). This suggests a link between the adakites (located west of the current position of the PFZ) resulting from the migration towards the southeast of the segment of the subducting slab that migrated with the PFZ and melted and metasomatized the mantle to produced the adakites (Fig. 1).

Johnston and Thorkelson (1997) explained the OIB-like signature of the Costa Rican volcanic front lavas by the opening of a "window" in the subducting slab following the collision of the Cocos Ridge (or older Galapagos-related tracks). A slab window can be produced when an active oceanic spreading center subducts beneath an arc producing a gap between the two subducting plates (Thorkelson and Taylor, 1989; Thorkelson, 1996). The dominant melting mechanism above a slab window is adiabatic mantle decompression controlled by extension in the lithosphere above the slab-free area (Thorkelson, 1996). The volume of magma production above a slab window is generally small compared to a mid-ocean ridge or an arc setting. The petrology of the erupted lavas above a slab-free region ranges from adakites and high Nb-basalts close to the edge of the subducting slab (Calmus et al., 2003; Aguillón-Robles et al., 2001; Defant et al., 1991) to alkaline and tholeiitic mafic volcanism produced by extension-related mantle upwelling (Hole et al., 1991; Gorring et al., 1997; Pallares et al., 2007).

Based on the slab window model, we would expect a MORB isotopic signature in the erupted lavas in southern Central America and $\mathrm{T}_{\mathrm{P}}$ in the range of the ambient mantle of $\sim 1350 \pm 50{ }^{\circ} \mathrm{C}$ (McKenzie et al., 2005; Herzberg et al., 2007; Herzberg and Asimow, 2008). Therefore, a simple slab window model does not adequately explain the relatively high $T_{P}\left(\max =1450{ }^{\circ} \mathrm{C}\right)$ computed from the alkaline basalts in Costa Rica and Panama and the recycled Seamount Province isotopic signature in some of the alkaline lavas behind the volcanic front in central Costa Rica (Hoernle et al., 2008; Gazel et al., 2009).

Detachment of the subducting slab will also produce a slab-free area, generally larger than a slab window caused by the subduction of an active spreading center. Structural weakness in the subducting slab can trigger a tear and lead to the rapid sinking of the detached slab 
A
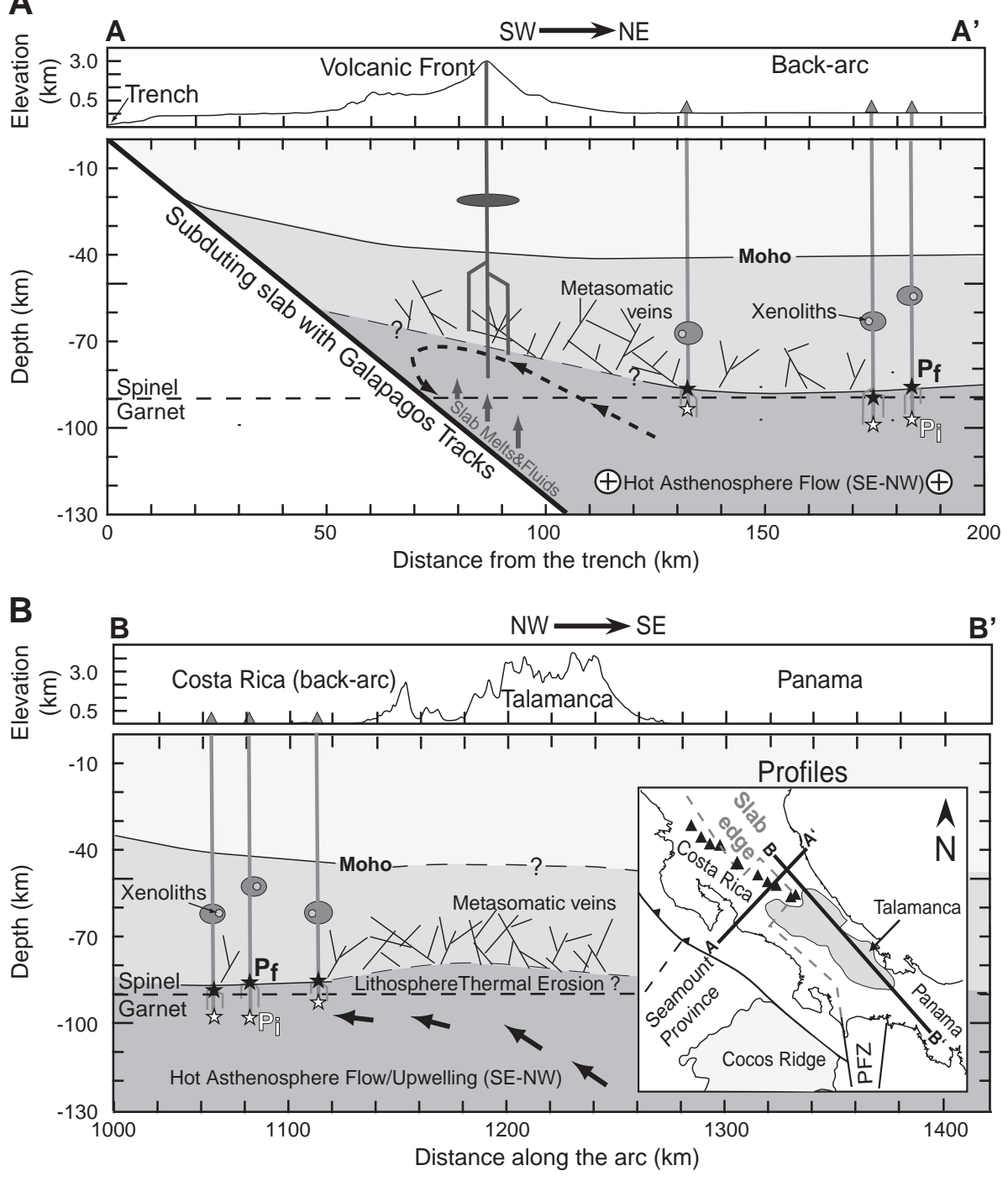

Fig. 8. A) Schematic profile across the volcanic front. B) Schematic profile along the volcanic front. In both profiles depth of the lithosphere-asthenosphere boundary in each locality is based on final melting pressures calculated from the primary magmas of alkaline lavas from Costa Rica and Panama (Table 3 ). The pressures are averages for each locality; the standard deviation of the mean is smaller than the "star" symbols of the initial $\left(\mathrm{P}_{\mathrm{i}}\right)$ and final $\left(\mathrm{P}_{\mathrm{f}}\right)$ melting pressures. The lithosphere-asthenosphere boundary topography is close to $\sim 85-90 \mathrm{~km}$. The thickness of the crust (Moho) is from Sallares et al. (2001) and MacKenzie et al. (2008). The direction of mantle flow is from Hoernle et al. (2008).

into the mantle (e.g., Davies and von Blanckenburg, 1995; Wortel and Spakman, 2000). This will produce an area free of subducting lithosphere that propagates laterally as the oceanic plate continues to tear along the strike of the subducting slab. The detached slab is replaced by upwelling asthenosphere (Levin et al., 2002; Ferrari, 2004; Pallares et al., 2007).

The numerous hotspot tracks and fracture zones on the subducting Cocos and Nazca plates (Werner et al., 1999) could make the subducting slab below Costa Rica and Panama relatively easy to tear and detach. We suggest that the collision of the Galapagos tracks with the arc 10-8 Ma ago (Denyer and Arias, 1991; Silver et al., 2004; Gazel et al., 2009) clogged or slowed the subduction processes and triggered the detachment of a segment of the subducting slab below Costa Rica and Panama (Fig. 9). The detached slab was replaced by hot and buoyant asthenosphere as suggested for northern Central America and Mexico (Rogers et al., 2002; Ferrari, 2004).

This process differs in southern Central America because the geochemical signature of the alkaline lavas (even the ones with minimal slab signature) requires the contribution of a Galapagos Plume component. Abratis and Wörner (2001) suggested that this signature resulted from Galapagos Plume flow beneath southern Costa Rica/ Panama. O'Connor et al. (2007) showed that the standard fixed hotspot age-distance correlation does not explain the Galapagos Plume behavior with a complex interaction with the Cocos Ridge at a significant distance from the plume axis (Meschede et al., 1998; O'Connor et al., 2007). An important piece of evidence of this long-term plume-ridge interaction is the Cocos Island and near-by seamounts located in the middle of the Cocos Ridge $\sim 600 \mathrm{~km}$ away from modern the Galapagos Plume axis a the Galapagos islands (Meschede et al., 1998; Werner et al., 2003; O'Connor et al., 2007). A "classic" linear agedistance progression from the plume axis (fixed at the modern day Galapagos Islands) predicts an age of $\sim 9$ m.y. for Cocos Island. Instead, geochronology and paleomagnetic studies confirm an anomalously young age of $\sim 2$ m.y. (Castillo et al., 1988; O'Connor et al., 2007 and references therein) not consistent with the classic model.

Recent geophysical studies provide evidence of a possible thermal anomaly, located $\sim 300 \mathrm{~km}$ below the Cocos Ridge. This anomaly extends $\sim 1200 \mathrm{~km}$ from the Galapagos islands to southern Central America (Montelli et al., 2006). These long-term plume-ridge interactions can be explained by a combination of plume movement within the mantle "wind" and plume capture by a ridge as suggested by Tarduno et al. (2009).

The slab detachment possibly occurred after 10-8 Ma (Gazel et al., 2009). The computed mantle $T_{P} S$ from the alkaline lavas closer in age to 


\section{Pliocene-Recent}
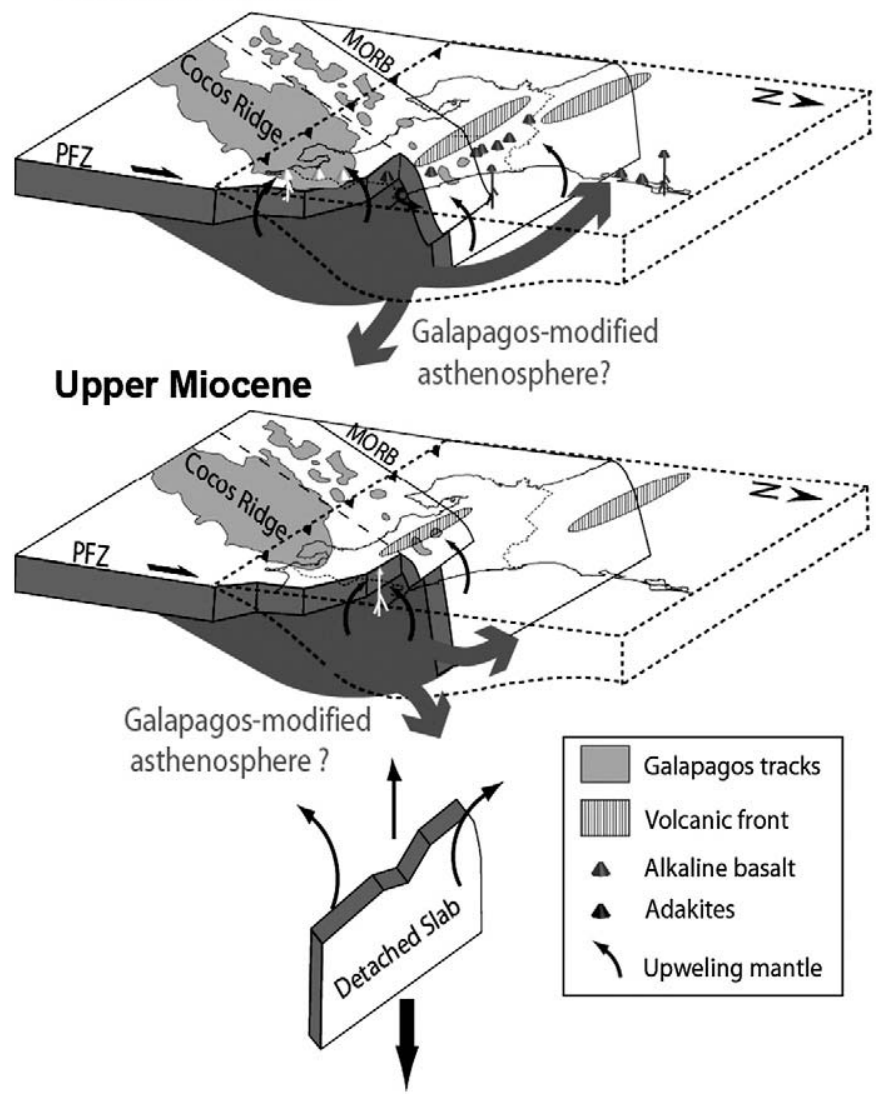

Fig. 9. Schematic model of the different geologic processes required to explain the Galapagos signature in the lavas of southern Central America. Galapagos tracks initially collided with the convergent margin and clogged the subduction system during the Upper Miocene $(\sim 10-8 \mathrm{Ma})$. This collision triggered the detachment of a segment of the subducting slab. The detachment was followed by mantle upwelling and the possible influx of Galapagos-modified asthenosphere below southern Central America through the "slab-free area". The adakites were produced by the interaction of upwelling mantle with the edge of the subducting plate. The geochemical signature of central Costa Rican volcanic front lavas is also consistent with the reaction of melts from the subducting slab and the mantle. The structure of the subduction zone is based on the work of Protti et al. (1994). PFZ: Panama Fracture Zone, EPR: East Pacific Rise; QSC: Quesada Sharp Contortion.

the detachment are in range with expected ambient $\mathrm{T}_{\mathrm{P}} \sim 1380-1410{ }^{\circ} \mathrm{C}$ (Fig. 9). It is after $4 \mathrm{Ma}$ when a mantle hotter than ambient is recorded in the alkaline lavas of Nicaragua, Costa Rica and Panama (Fig. 10). The slab-free area correlates with the highest elevations (e.g., the Talamanca Cordillera) of $\sim 4 \mathrm{~km}$ in southern Central America (Fig. 8). These elevations are possibly related to the isostatic effect produced by hot mantle upwelling after the slab detachment in this area together with shortening related to the collision of the Cocos Ridge.

Combining the results from seismic anisotropy and correlations of isotopic composition with distance along the volcanic front from central Costa Rica to northwest Nicaragua, Hoernle et al. (2008) proposed a northwest arc-parallel mantle flow at a rate $60-190 \mathrm{~mm} /$ yr. Gazel et al. (2009) showed that the Seamount Province Component of the subducting Galapagos Hostpot tracks first appeared in Costa Rica $6.5 \mathrm{Ma}$ ago, constraining the rate to be $\sim 60 \mathrm{~mm} / \mathrm{yr}$. Our new age data from the back-arc alkaline basalts in Costa Rica and Nicaragua show an age migration of $40 \mathrm{~mm} / \mathrm{yr}$ (Fig. 1) towards the northwest, consistent with Hoernle et al. (2008) mantle flow model.

Therefore, the age progression (Fig. 1) and the arc-parallel mantle flow possibly represent northern flow of Galapagos-modified asthenosphere (Fig. 10). The age progression of back-arc magmatism in Costa Rica and Nicaragua can be explained by the interaction of this Galapagos-modified asthenosphere and volatile-rich subductionmodified ambient mantle. As the hotter Galapagos-modified astheno- sphere moved towards the northwest (following the strike of the subducting slab), triggering melting in the ambient mantle.

\section{Conclusions}

Petrology suggests that there are three main source lithologies for the lavas collected in this study. For the alkaline lavas in Costa Rica and Panama the source is mantle peridotite (sometimes metasomatized by $\mathrm{CO}_{2}$ ) and pyroxenite veins. The adakites were produced by melting the mantle wedge metasomatized by the recycling of Galapagos tracks. The OIB-like signature in the volcanic front lavas from southern Central America is the result of mixture between mantle melts and slab melts from the subducting Galapagos tracks.

Mantle $T_{\mathrm{P}} \mathrm{s}$ from primary magmas from Nicaragua, Costa Rica and Panama are in range with ambient mantle for the units older than 4.0 Ma. $\mathrm{T}_{\mathrm{P}}$ increased to a maximum of $1450{ }^{\circ} \mathrm{C}$ in the younger units suggesting the influx of hotter asthenosphere below the arc. Initial melting pressures for calculated primary magmas range between 3.0 and $2.7 \mathrm{GPa}$ at garnet stability field. The average final melting pressures range between 2.7 and $2.5 \mathrm{GPa}$ interpreted as the lithosphere-asthenosphere boundary at $\sim 90-85 \mathrm{~km}$.

$\mathrm{Sr}, \mathrm{Nd}$ and $\mathrm{Pb}$ isotope systematics together with trace element data suggest that the Seamount Province Component is a recently arrived ( 6.5 Ma) recycled component from the subducting Galapagos tracks in front of central Costa Rica. The adakites in Panama/Costa Rica are also the result of the reaction of melts, but from the subducting Cocos/ Coiba Ridge with the mantle wedge.

We consider that the best way to explain the new data presented here is a model that involves slab detachment triggered by the collision of the Galapagos Hotspot tracks with the arc, followed by the influx of a relatively hotter asthenosphere that interacted with a subduction-metasomatized mantle.

\section{Acknowledgments}

Field work was supported by G. Alvarado from the Central American School of Geology at the University of Costa Rica and O. Arias and F. Cervantes from the Instituto Costarricence de Electricidad. Field assistance by S. T. Carr is gratefully acknowledged. D. Symanski and S. Hauff provided valuable analytical support. L. Danyushevsky kindly provided the new version of Petrolog software. Revisions by N. Sou and L. Patino improved the original manuscript. Thorough revisions and comments by M. Blondes, Alan Hastie and the editorial work by A. Kerr are highly appreciated. This research is the result of collaboration between Lamont-Doherty Earth Observatory (LDEO contribution no.

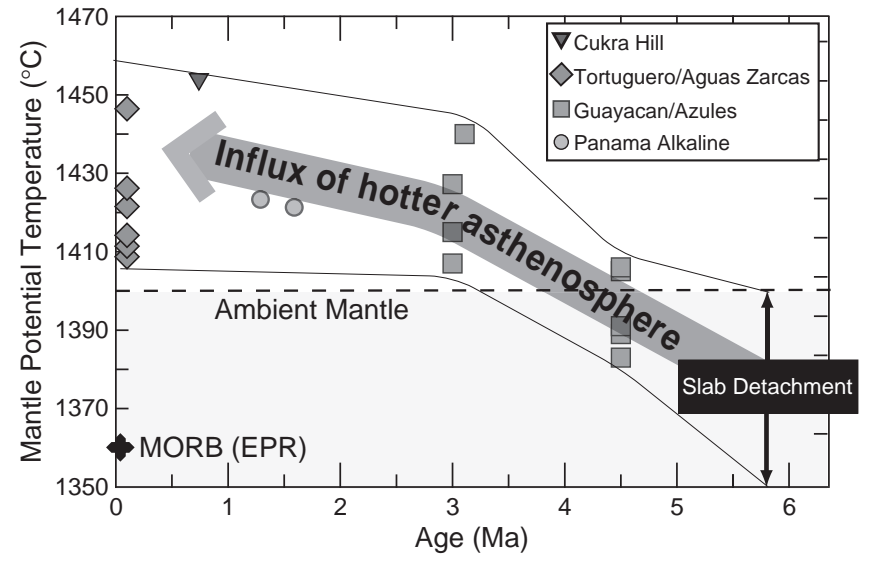

Fig. 10. Mantle Potential Temperautre $\left(T_{P}\right)$ vs. the age of the units that yield successfu petrologic solutions (Table 3 ). The slab detachment possibly occurred between 8 and $6 \mathrm{Ma}$ after the collision of Galapagos Hotspot tracks with the trench 10-8 Ma the range of $\mathrm{T}_{\mathrm{P}}$ expected from a slab detachment is in the ambient mantle range $\left(1350 \pm 50{ }^{\circ} \mathrm{C}\right)$. Notice how the $\mathrm{T}_{\mathrm{P}}$ increased in the units younger than $4 \mathrm{Ma}$. 
7409), the Department of Earth and Planetary Sciences at Rutgers University and IFM-GEOMAR. This work was supported through the NSF Margins Program, grants EAR0203388 and NSF OCE 0505924, the DFG Collaborative Research Center (SFB) 574 "Volatiles and Fluids in Subduction Zones" at Kiel University (contribution no. 201) and by the Geological Society of America Student Research Award.

\section{Appendix A}

\section{A.1. Methods for primary magma calculation}

Table 3 reports the primary magmas compositions, mantle potential temperatures, source melt fractions, and melting pressures from the alkaline lavas from Nicaragua, Costa Rica and Panama. All modeled data are based on the implementation of PRIMELT2.XLS (Herzberg and Asimow, 2008). PRIMELT2.XLS provides for each primary magma the olivine liquidus temperature $\mathrm{T}_{\mathrm{OL}}$ at $1 \mathrm{~atm}$ and the mantle potential temperature $T_{p}$. Adiabatic melting paths of Iwamori et al. (1995) were used to obtain: $\mathrm{T}_{\mathrm{p}}\left({ }^{\circ} \mathrm{C}\right)=1463+12.74 \mathrm{MgO}$ $-2924 / \mathrm{MgO}$ (Herzberg et al., 2007). Because both $\mathrm{T}_{\mathrm{OL}}$ and $\mathrm{T}_{\mathrm{P}}$ are dependent on the $\mathrm{MgO}$ content of the primary magma (Herzberg et al., 2007), the accuracy of the former is a guide to the precision of the latter. For any specific peridotite composition, accuracy of $\mathrm{T}_{\mathrm{OL}}$ is $\pm 31^{\circ} \mathrm{C}$, and for $\mathrm{T}_{\mathrm{P}}$ is $\pm 60{ }^{\circ} \mathrm{C}$ at the $2 \sigma$ for fertile and depleted peridotite source having $\sim 8 \% \mathrm{FeO}$, the average $\mathrm{FeO}$ contents for natural fertile and depleted peridotite (Herzberg et al., 2007).

Melting of depleted peridotite propagates to calculated melt fractions that are too high, but with a negligible error in mantle
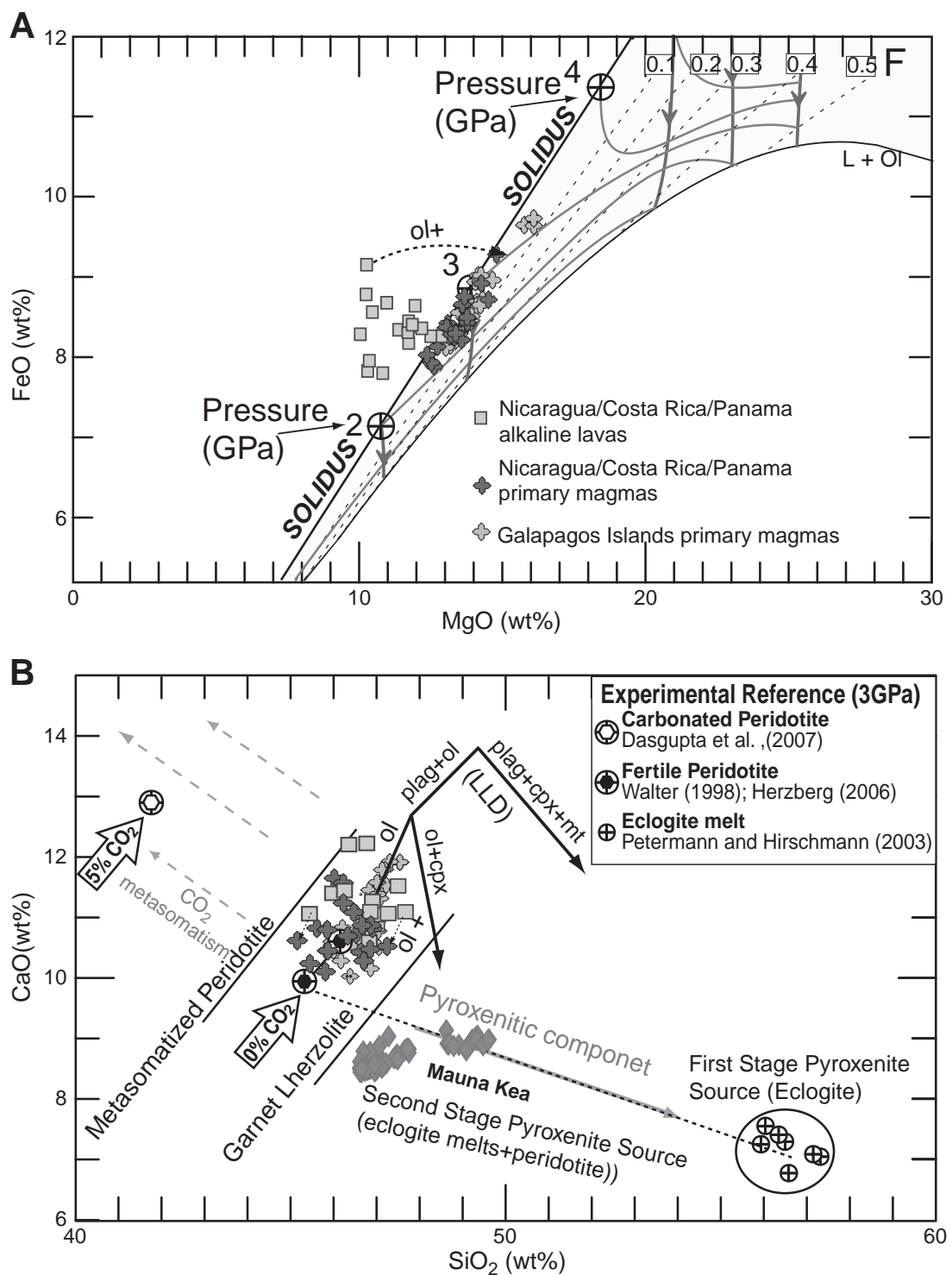

Fig. A.1. Petrology of primary magmas and possible source discrimination. A) Alkaline lavas from Costa Rica and Panama and the primary magmas inferred from them compared with primary magma compositions inferred for the modern day Galapagos Plume from Galapagos island lavas (Herzberg and Gazel, 2009). All primary magmas of fertile peridotite KR4003 plot within the gray field (Herzberg et al., 2007; Herzberg and Asimow, 2008). The intersections of the dark and light gray lines identify the composition of an accumulated fractional melt at the initial and final melting pressure, respectively. The dashed lines identify the melt fractions. The small arrow with a dashed line shows the effect of olivine addition $(\mathrm{ol}+$ ). Notice that there is an overlap between the low temperature (low $\mathrm{FeO}$ and $\mathrm{MgO}$ ) end of the Galapagos island primary magmas and the alkaline lavas from Nicaragua, Costa Rica and Panama. B) $\mathrm{CaO}-\mathrm{SiO}_{2}$ source composition discrimination for primary magmas, modified from Herzberg and Asimow (2008). The primary magmas inferred from the alkaline basalts in Costa Rica and Panama and from the Galapagos Plume are consistent with a volatile-deficient peridotite source. As suggested by Sobolev et al. (2005), mixing (solid state or reaction) between silicic melts from recycled oceanic crust and mantle peridotite can produce an array of second stage pyroxenitic source compositions (represented by the dashed line). Primary magmas from Mauna Kea (Herzberg, 2006) are consistent with melts produced from a second stage pyroxenite source. Two fractionation trends were modeled (LLD), one includes olivine $(\mathrm{ol})+$ plagioclase $(\mathrm{plag})+$ clinopyroxene $(\mathrm{cpx})+$ magnetite $(\mathrm{mt})$ and the other excludes plagioclase. These liquid lines of descent were modeled using Petrolog Software, with the parameters of Beattie (1993), Ariskin and Barmina (1999) and a FMQ buffer. 
potential temperature. Melt fraction is more difficult to quantify than mantle potential temperature because it is strongly dependent on the composition of the source (Herzberg and O'Hara, 2002; Herzberg et al., 2007; Herzberg and Asimow, 2008). A detailed discussion of the effects of variation of $\mathrm{FeO}$ composition of the mantle peridotite source in the calculation of primary magmas is presented in Herzberg and Gazel (2009). $\mathrm{Fe}_{2} \mathrm{O}_{3}$ is calculated based on OIB-like $\mathrm{Fe}_{2} \mathrm{O}_{3} / \mathrm{TiO}_{2} \sim 1$ (Herzberg and Asimow, 2008).

The source of the lavas needs to be a volatile-deficient mantle peridotite. The data is filtered based on the parameters described by Sobolev et al. (2005), Herzberg (2006) and Dasgupta et al. (2007). All primary magmas of fertile peridotite KR-4003 plot within the gray field (Herzberg et al., 2007; Herzberg and Asimow, 2008) in Fig. A.1A. The primary magmas calculated from the alkaline basalts in Nicaragua, Costa Rica and Panama plotted in Fig. A.1B are consistent with melts produced from a peridotite source.

Because fractional crystallization does not preserve in the geochemistry of the T-P conditions of melt formation in the mantle, PRIMELT2, only provides successful information about source temperature if the primary magma only gained or lost olivine before solidifying to a primitive rock. Most natural basalts crystallized clinopyroxene and/or plagioclase together with olivine and those samples cannot be modeled accurately at the present state of knowledge.

\section{A.2. Geobarometer from the primary magmas}

We assumed that primary magmas formed by accumulated fractional melting. The initial melting pressure $\left(\mathrm{P}_{\mathrm{i}}\right)$ and final melting pressure $\left(\mathrm{P}_{\mathrm{f}}\right)$ of the melt column are indicated in the $\mathrm{FeO}-\mathrm{MgO}$ diagram (Fig. A.1A) by the dark gray and light gray lines, respectively. These have been calculated by forward simulations of fractional melting of fertile peridotite (Herzberg and O'Hara, 2002). The final melting pressure is useful because it allows us to interpret the depth of the melting column and in our case to approximate the lithosphere-asthenosphere boundary. $\mathrm{P}_{\mathrm{i}}$ and $\mathrm{P}_{\mathrm{f}}$ can be inferred by simply plotting $\mathrm{FeO}$ and $\mathrm{MgO}$ for a PRIMELT2 primary magma in Fig. A.1A.

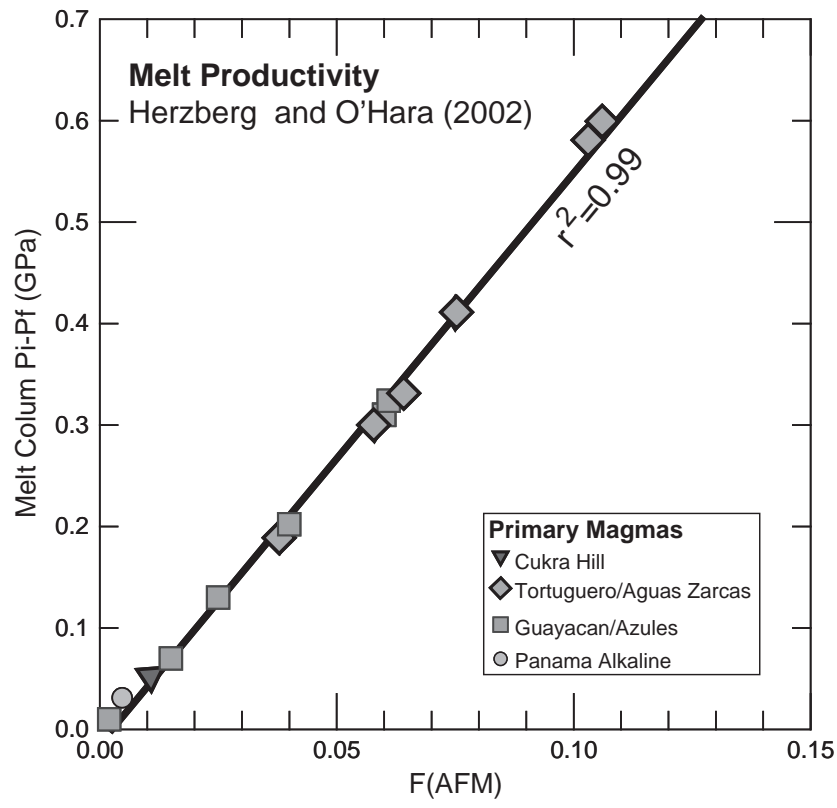

Fig. A.2. Results of calculated melt column and melt fraction from the alkaline basalt primary magmas plotted in the melt productivity line (for $\mathrm{F}<0.1$ and $\mathrm{P}_{\mathrm{i}} \sim 2.7-3.0 \mathrm{GPa}$ ) from Herzberg and O'Hara (2002).
Alternatively, these pressures can be calculated using the primary magma information computed from Table 3, with the following equations:

$\mathrm{P}_{\mathrm{i}}=11.248 \mathrm{MgO}-13700(1 / \mathrm{MgO})^{3}-8.13(\ln (\mathrm{MgO}))^{3}$

where the difference between calculated $\mathrm{P}_{\mathrm{i}}$ and those shown in Fig. A. $1 \mathrm{~A}$ by the light gray lines is $\pm 0.20 \mathrm{GPa}$ at the $2 \sigma$ level.

We can represent the depth of the melting column to the melt fraction with the following equation:

$\mathrm{P}_{\mathrm{i}}-\mathrm{P}_{\mathrm{f}}=\mathrm{aF}+\mathrm{bF}^{2}$

where, $\mathrm{F}$ is the aggregated fractional melting (AFM) melt fraction from Table 3, $\mathrm{P}_{\mathrm{i}}$ is from Eq. (A.1) from Herzberg and Gazel (2009) and $\mathrm{a}=4.659$ and $\mathrm{b}=10.240$ are melt productivity constants for $\mathrm{P}_{\mathrm{i}} \sim 3.0$ $2.7 \mathrm{GPa}$ from Herzberg and O'Hara (2002). Fig. A.2 shows the calculated $\mathrm{P}_{\mathrm{i}}-\mathrm{P}_{\mathrm{f}}$ results for the primary magmas computed in this study plotted in the melt productivity line from Herzberg and O'Hara (2002).

\section{Appendix B. Supplementary data}

Supplementary data to this article can be found online at doi:10.1016/j.lithos.2010.10.008.

\section{References}

Abratis, M., Wörner, G., 2001. Ridge collision, slab-window formation, and the flux of Pacific asthenosphere into the Caribbean realm. Geology 29, 127-130.

Aguillón-Robles, A., Calmus, T., Benoit, M., Bellon, H., Maury, R.O., Cotten, J., Bourgois, J., Michaud, F., 2001. Late Miocene adakites and Nb-enriched basalts from Vizcaino Peninsula, Mexico: indicators of East Pacific Rise subduction below southern Baja California? Geology 29, 531-534.

Albarède, F., Luais, B., Fitton, G., Semet, M., Kaminski, E., Upton, B.G.J., Bachelery, P., Cheminee, J.L., 1997. The geochemical regimes of Piton de la Fournaise volcano (Reunion) during the last 530,000 years. Journal of Petrology 38, 171-201.

Alvarado, G.E., Dengo, C., Martens, U., Bundschuh, J., Aguilar, T., Bonis, B., 2007. Stratigraphy and geologic history, in Central America. In: Bundschuh, J., Avarado, G. (Eds.), Geology, Resources and Hazards. Taylor and Francis, Leiden, pp. 345-394.

Ariskin, A.A., Barmina, G.S., 1999. An empirical model for the calculation of spinel-melt equilibria in mafic igneous systems at atmospheric pressure: 2. Fe Ti oxides. Contribuitions to Mineralogy and Petrology 134, 251-263.

Beattie, P. 1993. Olivine-melt and orthopyroxene-melt equilibria. Contributions to Mineralogy and Petrology 115, 103-111.

Bellón, H., Tournón, J., 1978. Contribution de la géochronométrie K-Ar a l’etude du magmatism de Costa Rica, Amérique Central. Bulletin de la Societe Géologique de France 20 (6), 955-959.

Benjamin, E.R., Plank, T., Wade, J.A., Kelley, K.A., Haun, E.H., Alvarado, G.E., 2007. High water contents in basaltic magmas from Irazu Volcano, Costa Rica. Journal of Volcanology and Geothermal Research 168, 68-92.

Bindeman, I.N., Eiler, J.M., Yogodzinski, G.M., Tatsumi, Y., Stern, C.R., Grove, T.L. Portnyagin, M., Hoernle, K., Danyushevsky, L.V., 2005. Oxygen isotope evidence for slab melting in modem and ancient subduction zones. Earth and Planetary Science Letters 235, 480-496.

Bryant, J.A., Yogodzinski, G.M., Hall, M.L., Lewicki, J.L., Bailey, D.G., 2006. Geochemical constrains on the origin of volcanic rocks from the Andean northern volcanic zone, Ecuador. Journal of Petrology 47 (6), 1147-1175.

Calmus, T., Aguillon-Robles, A., Maury, R.C., Bellon, H., Benoit, M., Cotten, J., Bourgois, J. Michaud, F., 2003. Spatial and temporal evolution of basalts and magnesian andesites ("bajaites") from Baja California, Mexico: the role of slab melts. Lithos 66, 77-105.

Carr, M.J., Feigenson, M.D., Bennett, E.A., 1990. Incompatible element and isotopic evidence for tectonic control of source mixing and melt extraction along the Central American arc. Contributions to Mineralogy and Petrology 105, 369-380.

Carr, M.J., Feigenson, M.D., Patino, L.C., Walker, J.A., 2003. Volcanism and geochemistry in Central America: progress and problems. In: Eiler, J., Abers, G. (Eds.), Inside the Subduction Factory. : Geophysical Monograph Series, 138. AGU, Washington, D. C. pp. 153-179.

Carr, M.J., Saginor, I., Alvarado, G.E., Bolge, L., Lindsay, F., Milidakis, K., Turrin, B., Feigenson, M.D., Swisher III, C., 2007. Element fluxes from the volcanic front of Nicaragua and Costa Rica. Geochemistry, Geophysics, Geosystems 8 (6), Q06001. doi:10.1029/2006GC001396.

Castillo, P., Batiza, R., Vanko, D., Malavassi, E., Barquero, J., Fernandez, E., 1988. Anomalously young volcanoes on old hot-spot traces: geology and petrology of Cocos Island. Geological Society of America Bulletin 100, 1400-1414. 
Dasgupta, R., Hirschmann, M.M., Smith, N.D., 2007. Partial melting experiments of peridotite $+\mathrm{CO}_{2}$ at $3 \mathrm{GPa}$ and genesis of alkalic ocean island basalts. Journal of Petrology 48, 2093-2124.

Davies, J.H., Von Blanckenburg, F., 1995. Slab breakoff: a model of lithosphere detachment and its test in the magmatism and deformation of collisional orogens. Earth and Planetary Science Letters 129, 85-102.

Defant, M.J., Drummond, M.S., 1990. Derivation of some modern arc magmas by melting of young subducted lithosphere. Nature 347, 662-665.

Defant, M.J., Richerson, P.M., Deboer, J.Z., Stewart, R.H., Maury, R.C., Bellon, H., Drummond, M.S., Feigenson, M.D., Jackson, T.E., 1991. Dacite genesis via both slab melting and differentiation: petrogenesis of La Yeguada volcanic complex, Panama. Journal of Petrology 32, 1101-1142.

Defant, M.J., Jackson, T.E., Drummond, M.S., Deboer, J.Z., Bellon, H., Feigenson, M.D., Maury, R.C., Stewart, R.H., 1992. The geochemistry of young volcanism throughout western Panama and southern Costa Rica: an overview. Journal of the Geological Society $149,569-579$.

DeMets, C., 2001. A new estimate for present-day Cocos-Caribbean plate motion: implications for slip along the Central American volcanic arc. Geophysical Research Letters 28, 4043-4046.

Dengo, G., 1962. Tectonic-igneous sequence in Costa Rica. In: Engel, A.E.J., James, H.J., Leonard, B.F. (Eds.), Geological Society of America Special Volume In Honor To A. F. Budington, pp. 133-161.

Dengo, G., 1985. Mid America: tectonic setting for the Pacific margin from southern Mexico to northwestern Columbia. In: Nairn, A.E.M., Stechli, F.G. (Eds.), The Ocean Basins and Margins. Plenum Press, New York, pp. 123-180.

Denyer, P., Arias, O., 1991. Estratigrafía de la región central de Costa Rica. Revista Geológica de America Centra 12, 1-59. http://www.geologia.ucr.ac.cr/revista/ revista_geol.html.

Feigenson, M.D., Carr, M.J., 1986. Positively correlated Nd and Sr isotope ratios of lavas from the Central American volcanic front. Geology 14, 79-82.

Feigenson, M.D., Carr, M.J., 1993. The source of Central American lavas: inferences from geochemical inverse modeling. Contributions to Mineralogy and Petrology 113 , 226-235.

Feigenson, M.D., Carr, M.J., Maharaj, S.V., Juliano, S., Bolge, L.L., 2004. Lead isotope composition of central American volcanoes: influence of the Galapagos plume. Geochemistry, Geophysics, Geosystems 6, 6001. doi:10.1029/2006GC001396.

Ferrari, L., 2004. Slab detachment control on mafic volcanic pulse and mantle heterogeneity in central Mexico. Geology 32, 77-80.

Foley, S.F., Barth, M.G., Jenner, G.A., 2000. Rutile/melt partition coefficients for trace elements and an assessment of the influence of rutile on the trace element characteristics of subduction zone magmas. Geochimica et Cosmochimica Acta 64, 933-938.

Foley, S., Tiepolo, M., Vannucci, R., 2002. Growth of early continental crust controlled by melting of amphibolite in subduction zones. Nature 417, 837-840.

Galer, S.J.G., Abouchami, W., 1998. Practical application of lead triple spiking for correction of instrumental mass discrimination. Mineralogical Magazine 62A, 491-492.

Garbe-Schönberg, C.D., 1993. Simultaneous determination of thirty-seven trace elements in twenty-eight international rock standards by ICP-MS. Geostandards and Geoanalytical Research 17, 81-97.

Gazel, E., 2003. Las series alcalinas del Plioceno de Costa Rica: Distribución espacial y relación con una fuente mantelica tipo OIB. Revista Geológica de America Central 29, 87-94. http://www.geologia.ucr.ac.cr/revista/revista_geol.html.

Gazel, E., Carr, M.J., Hoernle, K., Feigenson, M.D., Szymanski, D., Hauff, F., van den Bogaard, P., 2009. Galapagos-OIB signature in southern Central America: mantle refertilization by arc-hot spot interaction. Geochemistry, Geophysics, Geosystems 10 (32), O02S11. doi:10.1029/2008GC002246.

Gorring, M.L., Kay, S.M., Zeitler, P.K., Ramos, V.A., Rubiolo, D., Fernandez, M.I., Panza, J.L., 1997. Neogene Patagonian plateau lavas: continental magmas associated with ridge collision at the Chile Triple Junction. Tectonics 16, 1-17.

Goss, A.R., Kay, S.M., 2006. Steep REE patterns and enriched Pb isotopes in southern Central American arc magmas: evidence for forearc subduction erosion? Geochemistry, Geophysics, Geosystems 7, Q05016. doi:10.1029/2005GC001163.

Hannah, R.S., Vogel, T.A., Patino, L.C., Alvarado, G.E., Perez, W., Smith, D.R., 2002. Origin of silicic volcanic rocks in Central Costa Rica: a study of a chemically variable ashflow sheet in the Tiribi Tuff. Bulletin of Volcanology 64 (2), 117-135.

Harpp, K.S., Wanless, V., Otto, R., Hoernle, K., Werner, R., 2005. The Cocos and Carnegie aseismic ridges: a trace element record of long-term plume-spreading center interaction. Journal of Petrology 46, 109-133.

Hart, S.R., Brooks, C., 1974. Clinopyroxene-matrix partitioning of K, Rb, Cs, and Ba. Geochimica et Cosmochimica Acta 38, 1799-1806.

Hauff, F., Hoernle, K.A., van den Bogaard, P., Alvarado, G.E., Garbe-Schönberg, D., 2000. Age and geochemistry of basaltic complexes in western Costa Rica: contributions to the geotectonic evolution of Central America. Geochemistry, Geophysics, Geosystems 1, 1009. doi:10.1029/1999GC000020.

Herrstrom, E.A., Reagan, M.K., Morris, J.D., 1995. Variations in lava composition associated with flow of asthenosphere beneath southern Central America. Geology 23, 617-620.

Herzberg, C., 2006. Petrology and thermal structure of the Hawaiian plume from Mauna Kea volcano. Nature 444, 605-609.

Herzberg, C., Asimow, P.D., 2008. Petrology of some oceanic island basalts: PRIMELT2. XLS software for primary magma calculation. Geochemistry, Geophysics, Geosystems 9, Q09001. doi:10.1029/2008GC002057.

Herzberg, C., Gasparik, T., 1991. Garnet and pyroxenes in the mantle: a test of the majorite fractionation hypothesis. Journal of Geophysical Research, Solid Earth 96, 16263-16274.
Herzberg, C., Gazel, E., 2009. Petrological evidence for secular cooling in mantle plumes. Nature 458, 619-683.

Herzberg, C., O'Hara, M.J., 2002. Plume-associated ultramafic magmas of phanerozoic age. Journal of Petrology 43, 1857-1883.

Herzberg, C., Asimow, P.D., Arnt, N., Niu, Y.L., Lesher, C.M., Fitton, J.G., Cheadle, M.J., Saunders, A.D., 2007. Temperatures in ambient mantle and plumes: constraints from basalts, picrites, and komatiites. Geochemistry, Geophysics, Geosystems 8, Q02006-Q. doi:10.1029/2006GC001390.

Hoernle, K., Werner, R., Morgan, J.P., Garbe-Schonberg, D., Bryce, J., Mrazek, J., 2000. Existence of complex spatial zonation in the Galapagos plume for at least 14 m.y. Geology 28, 435-438.

Hoernle, K., White, J.D.L., van den Bogaard, P., Hauff, F., Coombs, D.S., Werner, R., Timm, C., Garbe-Schönberg, D., Reay, A., Cooper, A.F., 2006. Cenozoic intraplate volcanism on New Zealand: upwelling induced by lithospheric removal. Earth and Planetary Science Letters 248, 350-367.

Hoernle, K., Abt, D.L., Fischer, K.M., Nichols, H., Hauff, F., Abers, G.A., van den Bogaard, P., Heydolph, K., Alvarado, G., Protti, M., Strauch, W., 2008. Arc-parallel flow in the mantle wedge beneath Costa Rica and Nicaragua. Nature 451, 1094-1097.

Hole, M.J., Rogers, G., Saunders, A.D., Storey, M., 1991. Relation between alkalic volcanism and slab-window formation. Geology 19, 657-660.

Husen, S., Kissling, E., Quintero, R., 2002. Tomographic evidence for a subducted seamount beneath the Gulf of Nicoya, Costa Rica: the cause of the $1990 \mathrm{Mw}=7.0$ Gulf of Nicoya earthquake. Geophysical Research Letters 29, 1238. doi:10.1029/ 2001GL014045.

Husen, S., Quintero, R., Kissling, E., Hacker, B., 2003. Subduction-zone structure and magmatic processes beneath Costa Rica constrained by local earthquake tomography and petrological modeling. Geophysical Journal International 155, 11-32.

Ishizuka, O., Taylor, R.N., Yuasa, M., Milton, J.A., Nesbitt, R.W., Uto, K., Sakamoto, I., 2007. Processes controlling along-arc isotopic variation of the southern Izu-Bonin arc. Geochemistry Geophysics Geosystems 8, Q06008. doi:10.1029/2006GC001475.

Iwamori, H., McKenzie, D., Takahashi, E., 1995. Melt generation by isentropic mantle upwelling. Earth and Planetary Science Letters 134, 253-266.

Janoušek, V., Erban, V., Holub, F.V., Magna, T., Bellon, H., Mlčoch, B., Wiechert, U., Rapprich, V., 2010. Geochemistry and genesis of behind-arc basaltic lavas from Eastern Nicaragua. Journal of Volcanology and Geothermal Research 192, 232-256.

Johnston, S.T., Thorkelson, D.J., 1997. Cocos-Nazca slab window beneath Central America. Earth and Planetary Science Letters 146, 465-474.

Kay, R.W., 1978. Aleutian magnesian andesites: melts from the subducted Pacific Ocean crust. Journal of Volcanology and Geothermal Research 4, 117-132.

Kelemen, P.B., Yogodzinski, G.M., Scholl, D., 2003. Along-strike variation in the Aleutian Island Arc: genesis of high Mg\# andesites and implications for continental crust. In: Eiler, J., Abers, G. (Eds.), Inside the Subduction Factory. : Geophysical Monograph. Series 138. AGU, Washington, D. C, pp. 223-276.

Kelley, K.A., Plank, T., Grove, T.L., Stolper, E.M., Newman, S., Hauri, E., 2006. Mantle melting as a function of water content beneath back-arc basins. Journal of Geophysical Research, Solid Earth 111, B09208. doi:10.1029/2005JB003732.

Koppers, A.A.P., Staudigel, H., Wijbrans, J.R., Pringle, M.S., 1998. The Magellan seamount trail: implications for Cretaceous hotspot volcanism and absolute Pacific plate motion. Earth and Planetary Science Letters 163, 53-68.

Langmuir, C.H., Klein, E.M., Plank, T., 1992. Mantle flow and melt generation at midocean ridges. In: Morgan, J.P., Blackman, D.K., Sinton, J.M. (Eds.), Geophysical. : Monograph Series 71. AGU, Washington, D.C., pp. 183-280.

Leeman, W.P., Carr, M.J., Morris, J.D., 1994. Boron geochemistry of the Central American arc: constraints on the genesis of subduction-related magmas. Geochimica et Cosmochimica Acta 58, 149-168.

Levin, V., Shapiro, N., Park, J., Ritzwoller, M., 2002. Seismic evidence for catastrophic slab loss beneath Kamchatka. Nature 418, 763-767.

MacKenzie, L., Abers, G.A., Fischer, K.M., Syracuse, E.M., Protti, J.M., Gonzalez, V., Strauch, W., 2008. Crustal structure along the southern Central American volcanic front. Geochemistry Geophysics Geosystems 9, Q08S09. doi:10.1029/ 2008GC001991.

MacMillan, I., Gans, P.B., Alvarado, G., 2004. Middle Miocene to present plate tectonic history of the southern Central American volcanic arc. Tectonophysics 392, 325-348.

Macpherson, C.G., Hilton, D.R., Sinton, J.M., Poreda, R.J., Craig, H., 1998. High ${ }^{3} \mathrm{He} /{ }^{4} \mathrm{He}$ in the Manus backarc basin: implications for mantle mixing and the origin of plumes in the western Pacific Ocean. Geology 26, 1007-1010.

Márquez, A., Oyarzun, R., Dobias, M., Verma, S.P., 1999. Alkalic (ocean-island basalt type) and calc-alkalic volcanism in the Mexican volcanic belt: a case for plumerelated magmatism and propagating rifting at an active margin? Geology 27, 51-54.

Martin, H., Smithies, R.H., Rapper, R., Moyen, J.-F., Champion, D., 2005. An overview of adakite, tonalite-trondhjemite-granodiorite (TTG) and sanukitoid: relationships and some implications for crustal evolution. Lithos 79, 1-24.

McDonough, W.F., Sun, S.S., 1995. The composition of the Earth. Chemical Geology 120, 223-253.

McKenzie, D., Bickle, M.J., 1988. The volume and composition of melt generated by extension of the lithosphere. Journal of Petrology 29, 625-679.

McKenzie, D., Jackson, J., Priestley, K., 2005. Thermal structure of oceanic and continental lithosphere. Earth and Planetary Science Letters 233, 337-349.

Médard, E., Schmidt, M.W., Schiano, P., Ottolini, L., 2006. Melting of amphibole-bearing wehrlites: an experimental study on the origin of ultra-calcic nepheline-normative melts. Journal of Petrology 47, 481-504.

Meschede, M., Barckhausen, U., Worm, H.U., 1998. Extinct spreading on the Cocos Ridge. Terra Nova 10, 211-216. 
Montelli, R., Nolet, G., Dahlen, F.A., Masters, G., 2006. A catalogue of deep mantle plumes: new results from finite-frequency tomography. Geochemistry Geophysics Geosystems 7, Q11007. doi:10.1029/2006GC001248.

O'Hara, M.J., 1968. Are ocean floor basalts primary magmas? Nature 220, 683-686.

O'Connor, J.M., Stoffers, P., Wijbrans, J.R., Worthington, T.J., 2007. Migration of widespread long-lived volcanism across the Galapagos Volcanic Province: evidence for a broad hotspot melting anomaly? Earth and Planetary Science Letters 263, 339-354.

Pallares, C., Maury, R.C., Bellon, H., Royer, J.Y., Calmus, T., Aguillon-Robles, A., Cotten, J., Benoit, M., Michaud, F., Bourgois, J., 2007. Slab-tearing following ridge-trench collision: evidence from Miocene volcanism in Baja California, Mexico. Journal of Volcanology and Geothermal Research 161, 95-117.

Patino, L.C., Carr, M.J., Feigenson, M.D., 2000. Local and regional variations in Central American arc lavas controlled by variations in subducted sediment input Contributions to Mineralogy and Petrology 138, 265-283.

Peate, D.W., Pearce, J.A., 1998. Causes of spatial compositional variations in Mariana arc lavas: trace element evidence. Island Arc 7, 479-495.

Pertermann, M., Hirschmann, M.M., 2003. Anhydrous partial melting experiments on MORB-like eclogite: phase relations, phase compositions and mineral-melt partitioning of major elements at 2-3 GPa. Journal of Petrology 44, 2173-2201.

Pilet, S., Baker, M.B., Stolper, E.M., 2008a. Can alkaline basalts form by high degrees of melting of metasomatic veins? Geochimica et Cosmochimica Acta 72 (12), A749.

Pilet, S., Baker, M.B., Stolper, E.M., 2008b. Metasomatized lithosphere and the origin of alkaline lavas. Science 320, 916-919.

Protti, M., Gundel, F., McNally, K., 1994. The geometry of the Wadati-Benoiff zone under southern Central America and its tectonic significance-results from high resolution local seismographic. Physics of the Earth and Planetary Interiors 84, 271-287.

Putirka, K.D., 2005. Mantle potential temperatures at Hawaii, Iceland, and the midocean ridge system, as inferred from olivine phenocrysts: evidence for thermally driven mantle plumes. Geochemistry Geophysics Geosystems 6, 005L08. doi:10.1029/2005GC000915.

Ranero, C.R., von Huene, R., 2000. Subduction erosion along the Middle America convergent margin. Nature 404, 748-752.

Ranero, C.R., Morgan, J.P., McIntosh, K., Reichert, C., 2003. Bending-related faulting and mantle serpentinization at the Middle America trench. Nature 425, 367-373.

Reagan, M.K., Gill, J.B., 1989. Coexisting of calc-alkaline and high-Nb basalts from Turrialba volcano, Costa Rica: implications for residual titanates in arc magma sources. Journal of Geophysical Research-Solid Earth and Planets 94, 4619-4633.

Ringwood, A.E., 1990. Slab mantle interactions: petrogenesis of intraplate magmas and structure of the upper mantle. Chemical Geology 82, 187-207.

Rogers, R.D., Karason, H., van der Hilst, R.D., 2002. Epeirogenic uplift above a detached slab in northern Central America. Geology 30, 1031-1034.

Rychert, C.A., Shearer, P.M., 2009. A global view of the lithosphere-asthenosphere boundary. Science 324, 495-498.

Sallares, V., Danobeitia, J.J., Flueh, E.R., 2001. Lithospheric structure of the Costa Rican Isthmus: effects of subduction zone magmatism on an oceanic plateau. Journal of Geophysical Research, Solid Earth 106, 621-643.

Silver, E., Costa Pisani, P., Hutnak, M., Fisher, A., DeShon, H., Taylor, B., 2004. An 8-10 Ma tectonic event on the Cocos Plate offshore Costa Rica: result of the Cocos Ridge collision. Geophysical Research Letters 31, L18601. doi:10.1029/2004GL020272.

Smith, G.P., Wiens, D.A., Fischer, K.M., Dorman, L.M., Webb, S.C., Hildebrand, J.A., 2001. A complex pattern of mantle flow in the Lau back arc. Science 292, 713-716.
Sobolev, A.V., Hofmann, A.W., Sobolev, S.V., Nikogosian, I.K., 2005. An olivine-free mantle source of Hawaiian shield basalts. Nature 434, 590-597.

Stack, C., 1991. Inverse modeling of alkaline lavas from Guayacan, Costa Rica. Rutgers University M.S. Thesis, New Jersey, 52 pp.

Straub, S.M., LaGatta, A.B., Pozzo, A., Langmuir, C.H., 2008. Evidence from high-Ni olivines for a hybridized peridotite/pyroxenite source for orogenic andesites from the central Mexican Volcanic Belt. Geochemistry, Geophysics, Geosystems 9, Q03007. doi:10.1029/2007GC001583.

Sun, S.S., McDonough, W.F., 1989. Chemical and isotopic systematics of oceanic basalts: implications for mantle compositions and processes. In: Saunders, A.D., Norry, M.J. (Eds.), Magmatism in the Ocean Basins, Geological Society Special Publication 42, pp. 313-345.

Syracuse, E.M., Abers, G.A., 2006. Global compilation of variations in slab depth beneath arc volcanoes and implications. Geochemistry, Geophysics, Geosystems 7, Q05017. doi:10.1029/2005GC001045.

Syracuse, E.M., Abers, G.A., Fischer, K., MacKenzie, L., Rychert, C., Protti, J.M., Gonzalez, V., Strauch, W., 2008. Seismic tomography and earthquake locations in the Nicaraguan and Costa Rican upper mantle. Geochemistry Geophysics Geosystems 9, Q07S08. doi:10.1029/2008GC001963.

Tarduno, J., Bunge, H.P. Sleep, N., Hansen, U. 2009. The bent Hawaiian-Emperor Hotspot track: inheriting the mantle wind. Science 324, 50-53.

Thorkelson, D.J., 1996. Subduction of diverging plates and the principles of slab window formation. Tectonophysics 255, 47-63.

Thorkelson, D.J., Taylor, R.P., 1989. Cordilleran slab windows. Geology 17, 833-836.

Turner, S., Hawkesworth, C., 1998. Using geochemistry to map mantle flow beneath the Lau Basin. Geology 26, 1019-1022.

Vannucchi, P., Scholl, D.W., Meschede, M., McDougall-Reid, K., 2001. Tectonic erosion and consequent collapse of the Pacific margin of Costa Rica: combined implication from ODP Leg 170, seismic offshore data and regional geology of the Nicoya Peninsula. Tectonics 20, 649-668.

Vannucchi, P., Fisher, D.M., Bier, S., Gardner, T.W., 2006. From seamount accretion to tectonic erosion: formation of Osa Mélange and the effects of Cocos Ridge subduction in southern Costa Rica. Tectonics 25, TC2004. doi:10.1029/2005TC001855.

Wegner W., Wörner G. Harmon, R.S., Jicha, B., 2010. Magmatic history and character of the Central American Land Bridge region since Cretaceous time. Geological Society of America Bulletin. B30109, 12010. doi:10.1130/B30109.1.

Wendt, J.I., Regelous, M., Collerson, K.D., Ewart, A., 1997. Evidence for a contribution from two mantle plumes to island-arc lavas from northern Tonga. Geology 25, 611-614.

Werner, R., Hoernle, K., van den Bogaard, P., Ranero, C., von Huene, R., 1999. Drowned 14-m.y.-old Galapagos archipelago off the coast of Costa Rica: implications for tectonic and evolutionary models. Geology 27, 499-502.

Werner, R., Hoernle, K., Barckhausen, U., Hauff, F., 2003. Geodynamic evolution of the Galapagos hot spot system (Central East Pacific) over the past 20 m.y.: constraints from morphology, geochemistry, and magnetic anomalies. Geochemistry Geophysics Geosystems 4, 1108. doi:10.1029/2003GC000576.

Wiens, D.A., Kelley, K.A., Plank, T., 2006. Mantle temperature variations beneath backarc spreading centers inferred from seismology, petrology, and bathymetry. Earth and Planetary Science Letters $248,30-42$.

Wortel, M.J.R., Spakman, W., 2000. Geophysics - subduction and slab detachment in the Mediterranean-Carpathian region. Science 290, 1910-1917. 